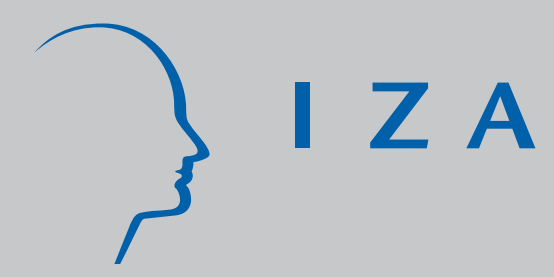

IZADP No. 1467

Does Work Pay in France? Monetary Incentives and the Guaranteed Minimum Income

Marc Gurgand

David N. Margolis

J anuary 2005 


\title{
Does Work Pay in France? Monetary Incentives and the Guaranteed Minimum Income
}

\author{
Marc Gurgand \\ Paris-Jourdan Sciences Economiques, \\ CREST and IRES \\ David N. Margolis \\ TEAM, University of Paris 1, \\ CNRS, CREST and IZA Bonn

\section{Discussion Paper No. 1467 \\ January 2005}

IZA

P.O. Box 7240

53072 Bonn

Germany

Phone: +49-228-3894-0

Fax: +49-228-3894-180

Email: iza@iza.org

\begin{abstract}
Any opinions expressed here are those of the author(s) and not those of the institute. Research disseminated by IZA may include views on policy, but the institute itself takes no institutional policy positions.

The Institute for the Study of Labor (IZA) in Bonn is a local and virtual international research center and a place of communication between science, politics and business. IZA is an independent nonprofit company supported by Deutsche Post World Net. The center is associated with the University of Bonn and offers a stimulating research environment through its research networks, research support, and visitors and doctoral programs. IZA engages in (i) original and internationally competitive research in all fields of labor economics, (ii) development of policy concepts, and (iii) dissemination of research results and concepts to the inter ested public.
\end{abstract}

IZA Discussion Papers often represent preliminary work and are circulated to encourage discussion. Citation of such a paper should account for its provisional character. A revised version may be available directly from the author. 
IZA Discussion Paper No. 1467

January 2005

\begin{abstract}
Does Work Pay in France? Monetary Incentives and the Guaranteed Minimum Income*

Most welfare programs generate high marginal tax rates on labor income. This paper uses a representative sample of individuals on France's main welfare program (the Revenu Minimum d'Insertion, or RMI) to estimate monetary gains to employment for welfare recipients. This is based on the distribution of potential monthly earnings faced by each individual, as inferred from the distribution of observed wages and working time. Taking account of the welfare earnings top-up program (intéressement), we find that gains are almost always positive, but that their amount is very low, especially for single mothers. Intéressement is found to have a small impact, because of its provisional nature. Gains are positively related $b$ the probability that a welfare recipient in 1996 will be observed in employment in 1998. Using a simple structural model, we interpret this as a labor supply effect.
\end{abstract}

JEL Classification: I38, J31, C34

Keywords: welfare, labor earnings, transfers, tax-system

Corresponding author:

David N. Margolis

TEAM

Université de Paris 1 Panthéon-Sorbonne

Maison des Sciences Economiques

106-112, boulevard de l'Hôpital

75647 Paris Cedex 13

France

Email: David.Margolis@univ-paris1.fr

\footnotetext{
* The authors are grateful to Cédic Afsa for his numerous comments and Luc Behaghel for outstanding research assistance. They would also like to thank Danièle Guillemot for helping provide access to the data and Cyril Hagneré for help into the French welfare system, as well as Jean-Claude Barbier, Jérôme Gauti é, Laurence Rioux, Daniel Szpiro and participants at the DREES workshop, the "Working Poor en France" conference and seminars at the Centre d'Etudes de l'Emploi, Université Lille I and Université Catholique de Louvain for their comments. This research was financed by a grant from the Ministry of Labour.
} 


\section{Introduction}

The debate surrounding the policy of a guaranteed minimum income has been lively in both the popular press and the scientific literature. Economists have tended to focus on the possible disincentive effects that such a policy might provide with respect to labor force participation because of the high effective marginal tax rate that it imposes at the bottom of the income distribution. This has come as a justification for implementing schemes that locally reduce marginal tax rates, such as negative income taxes. The vast majority of empirical studies have focused on the North American (and the United States in particular) labor markets (Moffitt, 2002), while it seems clear (in a prima facie sense) that an analysis of the policy of a guaranteed minimum income is likely to be more relevant for European countries, as the level and ubiquity of these policies is much more important on the eastern shore of the Atlantic.

This paper addresses this question by measuring the size of the monetary work incentive faced by recipients of the guaranteed minimum income program in France, i.e. the gap between the labor market income they can earn and the level of welfare. We take full account of the fact that individuals may face hours constraints on their working time (Dickens and Lundberg, 1993, Euwals and van Soest, 1999). As individuals face take-it-or-leave-it job offers comprised of a wage-hours pair, this gives rise to a discrete labor supply model. In this context, the graph of implicit marginal tax rates is not sufficient information to figure out the incentive effects of a policy, because not all points are available, and thus relevant, for individual decision-making.

We also depart from the accounting-representative household approach that is widely used to evaluate transfer programs along the lines of the OECD (2003) report "Making Work Pay". In these analyses, labor earnings are arbitrarily attributed to representative households for comparison with their transfer income. This has the clear disadvantage of ignoring the differences across individuals in their characteristics and actual labor market perspectives. $^{1}$

In this paper, we ask how much money each welfare beneficiary from a representative survey would gain if she were to be employed on the job that is typically accessible to her at some point in time, given her characteristics and the demand for labor. To this end, we estimate equations for the distribution of wages and working time offered by potential employers, given

\footnotetext{
${ }^{1}$ Concerning the RMI in France, see, for example, Padieu (1997), Join-Lambert (1998) and Gautié and Gubian (2000).
} 
worker productive characteristics. Distributions are parametric but flexible and fit the data very well. Estimates are based on observed earnings, with selectivity correction using non-wage income and demographics as instruments. Our counterfactual is thus to make every welfare recipient receive and accept a draw from these potential offers. We then measure their disposable income increase (or decrease) using all relevant features of the tax and transfer system. Put differently, we estimate the returns to work based on earnings typical of what each welfare leaver might get if working. When these returns are low, labor supply policies to increase employment may be warranted, especially if targeted on relevant sub-populations. We then estimate a structural model that relates these gains to observed employment status.

The estimation and simulation is based on a representative data set of RMI beneficiaries in December 1996 (Devenir des personnes sorties du $R M I)$ resurveyed in January 1998. Although there are other social programs that generate incentive problems, for reasons of clarity and data availability, we focus primarily on the main nationwide guaranteed minimum income program with almost unrestricted access, called the RMI (Revenu Minimum d'Insertion), that benefits approximately $3 \%$ of the population and is of central importance in the French welfare system.

Improving incentives while maintaining protection against poverty is a major issue of most welfare programs. The RMI program comprises a temporary scheme ("intéressement") that maintains part of the welfare transfer on top of wages for a limited amount of time (for the first 750 hours of work as of survey time, the rules having changed since then). It has the incentive effect of temporarily reducing the marginal tax rate from $100 \%$ to $50 \%$. When taking account of this scheme, we compute the present value of the job in this setting and compare it with the present value of receiving RMI forever.

Laroque and Salanié (2000) examine the impact of incentives on labor supply considering the whole fiscal system and total French population. Using a static structural model, they estimate that inactive women living in a couple require, on average, and extra 579 euros per month in order to participate, that single women would be willing to accept a reduction in labor income of 305-610 euros per month before withdrawing from the labor force (although single mothers would need to see their earnings increase to enter the labor force), and that the majority of men, single or in a couple, would be willing to work even at lower earnings levels than they currently receive. In this work, however, they exclude part-time jobs from their data and have incomplete information on household income. Laroque and Salanié 
(2002) introduce female part-time work. In this work, we concentrate on the population on welfare, that is most subject to high marginal tax rates, using a representative sample. As we will show here, part-time work is also relevant for men in this context, largely due to a particular public employment program called the Employment Solidarity Contract (Contrat emploi solidarité) whose effects are explicitly modeled. More importantly, the temporary incentive scheme (intéressement) is usually not taken into consideration when the welfare system is evaluated, in part because of lack of data. We reconstitute information on this scheme, so as to evaluate income changes more accurately.

The structure of the rest of this paper is as follows. In section 2 , a brief account of the French welfare system is presented with an emphasis on the RMI. In section 3 we lay out a model and the econometric techniques employed for estimating potential labor market earnings conditional on observable characteristics. Section 4 describes the data used for the estimation and discusses the estimation results. Section 5 describes the distribution of the size of the monetary incentives implied by the estimates in section 4 . Section 6 considers the link between the gains to employment and the observed probability of employment, while section 7 concludes.

\section{Welfare Income in France}

This paper focuses on France's guaranteed minimum income (RMI), a welfare program accessible to any person aged 25 and over, ${ }^{2}$ provided that the sum of all resources available to his or her household is below a threshold that depends on family composition. More than 1 million households receive payments from the RMI system, covering approximately $3 \%$ of the population. These take the form of a monetary transfer that brings household resources up to the threshold. Other guaranteed income programs (with restricted access) do exist, such as those for the elderly, handicapped, widows and widowers and single parents with children below $3 .^{3}$ These other programs are typically more generous than RMI, and the transfers for the handicapped and the elderly cover a large number of people, while the population covered by the widow/widower benefits is rather limited. However, the role of these transfers in affecting the labor market behavior of those concerned is likely to be quite different from that of the RMI. Finally, the unemployed who have exhausted their unemployment benefits have access

\footnotetext{
${ }^{2}$ This age restriction does not apply for people with underage dependents.

${ }^{3}$ This last benefit cannot be received for more than 3 years total.
} 
to a specific benefit whose amount is similar to that of RMI. ${ }^{4}$

When comparing labor income with welfare income, additional transfers related to family composition and housing must be considered. Most family composition-based benefits are means tested, increase with the number of children, and vary with the presence or absence of children under 3 years old. ${ }^{5}$ Among the housing-based benefits, households who rent their lodging (or own it and are paying interest) are eligible for subsidies that apply differently to the private and public sector housing. ${ }^{6}$ They depend on taxable income at a decreasing marginal rate, which varies with family composition and on the amount of the rent, and are subject to different thresholds based on the zone of habitation. ${ }^{7}$ In the typical situation, when taxable income is zero and the rent is below the threshold, the subsidy covers up to $90 \%$ of the rent. All of these transfers are included in the household resources when calculating eligibility for the RMI. ${ }^{8}$

Call $s_{R M I}$ the guaranteed threshold and $T(w)$ the net transfers available to a household with labor income $w$. In the absence of any further incentive, the household benefits from the RMI scheme when $w+T(w)<s_{R M I}$, in which case its guaranteed disposable income is $s_{R M I}$. Otherwise, its pre-tax income is $w+T(w)$. As such, the RMI generates a $100 \%$ implicit marginal tax rate on earnings such that household income is below the RMI threshold.

Intéressement reduces this rate to $50 \%$ and extends the range of affected earnings. If a recipient takes a job, only half of his labor income is considered when eligibility for further RMI transfers is determined: the criteria becomes $w / 2+T(w)<s_{R M I}$. Disposable income is then $w / 2+s_{R M I}$. But this is only

\footnotetext{
${ }^{4}$ Unfortunately, our data does not allow us to observe individuals who receive the single parents with young children benefit or the transfer in the event of unemployment benefit exhaustion.

${ }^{5}$ Every household responsible for at least 2 children is entitled to a transfer (Allocations familiales). The additional, means-tested, transfers considered in this paper are the Complement familial, Allocation pour jeune enfant and Allocation de rentrée scolaire. A subsidy for children in school which was introduced in 1995 (Aide à la scolarité) is not considered here. We also exclude the Allocation parentale d'éducation, which is available to every household with at least 2 children, of which one is less than 3 years old, provided one of the spouses does not work or works part time and can justify at least 2 years of work over the last 5 or 10 years (depending on the number of children).

${ }^{6}$ Allocation logement and Aide personalisée au logement.

${ }^{7}$ The taxable income considered is that of the previous year, something that we do not explicitly take into account in the simulations. As we use the current income, or expected income, for the calculation of tax rates, this is equivalent to imposing a form of stationarity in the income process.

${ }^{8}$ The housing subsidy receives a special tax treatment that is accounted for in our modelling of the system of taxes and transfers but whose complexities go beyond this general presentation.
} 
temporary and lasts for the first 750 hours worked. ${ }^{9}$ When this entitlement to intéressement is exhausted, the household faces the $100 \%$ implicit tax rate on earnings below the RMI threshold and the general income tax system for earnings above this level. This scheme is complicated by several rules that allow the hours counter to be reset to zero when additional transitions to and from employment take place. We do not consider these complications here, and compare income when continuously on RMI with income from a stable job. In one variation, we consider the case where the job terminates with a fixed probability every month, in which case the person falls back into RMI. ${ }^{10}$ Although a dynamic approach would be legitimate, one can still draw major insights from the (more frequently used) static labor supply approach.

This complex system gives rise to a characteristic profile for the RMI beneficiaries effective marginal tax rate on labor income. Setting intéressement aside for the moment, the marginal tax rate is $100 \%$ below the income threshold $\bar{w}$ that verifies $\bar{w}+T(\bar{w})=s_{R M I}$. Figure 1 depicts earned labor income versus disposable income of a single person that does not receive the housing subsidy. ${ }^{11}$ On the bottom line, the guaranteed income is 325 euros $^{12}$ (less than half of earnings from a month long full-time job at the minimum wage). For earnings beyond this amount, labor income is taxed at a marginal rate of $0 \%$ then $8 \%$ after 450 euros and $17 \%$ starting at earnings of approximately 900 euros.

Because RMI recipients are not subject to an income tax, but become so as soon as they leave the program, their marginal tax rate is locally infinity (at 325 euros in the single person example). This decrease in disposable income is even more pronounced for those eligible for a housing subsidy, because labor income is taken into account in the means-tested housing subsidy as soon as the person has left RMI (this feature has been corrected in recent legislation).

The budget set under intéressement is also presented on figure 1. The marginal rate is reduced to $50 \%$ and RMI eligibility is extended up to earnings of 650 euros because only half of the wage income is considered under

\footnotetext{
${ }^{9}$ The 750 hour limit was relevant in 1998, the period covered by our data. Since then, the time limit has been extended.

${ }^{10}$ This approach is equivalent to assuming either that there is no possibility of unemployment insurance or that the individual does not acquire enough work experience to be eligible for unemployment insurance when the job is lost.

${ }^{11}$ In this figure and the following one, the rules that were in effect in July 1998 are applied.

${ }^{12}$ All earnings amounts in this section refer to monthly earnings.
} 
this scheme. After 750 hours, the budget set drops down to the bottom line. Naturally, under this scheme, the effect of taxation and housing benefit loss after 650 euros is more pronounced under intéressement, as illustrated in the figure. Under intéressement there is much more incentive to take a 650 euros than, say, a 660 euros job. Such a shift of incentives towards lower wages (or, equivalently, part-time work) is a shared feature of negative income tax schedules (Moffit, 2003; Saez 2002).

At the other end of the spectrum, consider a couple with 3 children, one below 3, which receives a housing subsidy (figure 2). Resources are over 1,100 euros under the RMI. After the first 750 hours, intéressement is no longer available (bottom line), in which case the household becomes ineligible for the RMI once labor earnings exceed 538 euros since the household then attains the RMI threshold after adding in family benefits. The marginal effective tax rate drops below $100 \%$ for household earnings beyond 538 euros, but remains at about $20 \%$ on average until labor income reaches 2150 euros. This is because of the importance of means tested family-related transfers for this type of household. The tax rate then drops to less than $8 \%$ once it depends solely on the income tax, which is very favorable to large families, and starts increasing again only at very high wages. Because of these high marginal rates at low incomes, the budget sets with and without intéressement are less contrasted than in the single person example.

Based on these few cases, it is clear that the French welfare system imposes very high effective marginal tax rates on labor income, up to $100 \%$ (and locally infinity), over a large range of labor earnings, due to the accumulation of means-tested schemes. ${ }^{13}$ This point has often been noted in the literature (e.g. Laroque and Salanié (1999), among others). In this context, the presence of intéressement, though largely neglected in the literature, has the potential to have a large impact on incentives and behavior. Although the entire profile of the marginal tax rate is of interest, certain ranges of figures 1 and 2 may be more relevant than others for a given household when the jobs proposed by potential employers tend to be disproportionately situated in particular intervals on the labor earnings axis. The strategy of this paper is to identify the points that are relevant to the actual beneficiaries of RMI, and compare those potential incomes with their resources on welfare.

\footnotetext{
${ }^{13}$ L'Horty and Anne (2002), using a number of case studies, have illustrated the fact that additional programs independently implemented by local governments, when they exist, tend to increase further the marginal tax rates. Due to the lack of exhaustive data on these local-level programs, they are not considered in this paper.
} 


\section{The Model Framework}

In order to estimate the size of the differential between labor market earnings and the RMI, and the resulting impacts on labor supply, we need to be able to impute relevant wages and working hours for those individuals who receive the RMI. This implies the estimation of a model for the joint distribution of potential wage and hours combinations that are offered to individuals with a given set of observable characteristics, based on data on the observed earnings of a selected population. We make individuals draw in this distribution (unconditional on observed employment status) to form the distribution of their potential labor incomes and compare it with welfare. We then relate the resulting labor incentives to observed employment status, based on a simple static behavioral equation.

The huge discontinuities illustrated in figures 1 and 2 would generate ill-behaved likelihood functions if earnings and labor supply equations were to be estimated jointly. Indeed, a marginal change in the wage distribution parameters, for instance, can create a discontinuity in the employment probability. Laroque and Salanié (2000) suggest smoothing the disposable income function, but this is not realistic in our context given the large steps produced by intéressement. As a result, we proceed sequentially by first estimating the wage and hours distribution and then conditioning the structural labor supply model on these implied gains to employment.

\subsection{The Basic Model}

Suppose that employers propose jobs characterized by an hourly wage rate $\left(w^{d}\right)$ and a number of monthly hours worked $\left(h^{d}\right)$. Given the diversity of employers and jobs available in the labor market, a large number of $\left(w^{d}, h^{d}\right)$ pairs can be proposed in the economy to each individual. The distribution of proposed wage-hours pairs forms the labor demand set faced by the individual and is conditional upon his or her productive human capital characteristics $(X)$. We assume that demographic characteristics and family status do affect labor supply but do not affect productive capacities, and are thus not included in the vector $X$ that determines labor demand. These additional variables, and possibly some elements of $X$, are grouped into a vector $Z$ that affects preferences.

Utility is defined with respect to income and hours worked as

$$
U\left(D\left(w h, y_{0}, Z\right), h ; Z, \varepsilon\right)
$$

where $\varepsilon$ captures unobserved characteristics that affect preferences on top of 
$Z$. The function $D(\cdot)$ computes disposable income, based on labor earnings $(w h)$, wealth $\left(y_{0}\right)$ and family characteristics relevant to compute taxes and transfers (at most a subset of $Z$ ). When not working, utility is therefore $U\left(D\left(0, y_{0}, Z\right), 0 ; Z, \varepsilon\right)$ and depends only on $y_{0}, Z$ and $\varepsilon$.

We assume that individuals receive job offers from the joint distribution of $\left(w^{d}, h^{d} \mid X\right)$. A person will accept any such offer which provides at least the utility of not working, that is when:

$$
U\left(D\left(w^{d} h^{d}, y_{0}, Z\right), h^{d} ; Z, \varepsilon\right) \geq U\left(D\left(0, y_{0}, Z\right), 0 ; Z, \varepsilon\right)
$$

Even if $\varepsilon$ is independent from $\left(w^{d}, h^{d} \mid X\right)$, the distribution of observed wages and hours is not representative of the distribution of $\left(w^{d}, h^{d} \mid X\right)$ because condition 1 restricts the set of observed values. For instance, if $U_{D}^{\prime}>0$, observed wages may be on average higher than proposed wages. For this reason, selectivity must be accounted for when estimating the distribution of $\left(w^{d}, h^{d} \mid X\right)$. The existence of variables in $Z$ and $y_{0}$ that do not affect proposed wages and hours is sufficient to identify conditional means. However, parametric distributional assumptions are needed to recover the full distribution.

With an estimate of the distribution of $\left(w^{d}, h^{d} \mid X\right)$ we can proceed in two directions. First, we may describe the size of the monetary work incentive provided by the legislation to any individual, as measured by the distribution of

$$
D\left(w^{d} h^{d}, y_{0}, Z\right) \mid X-D\left(0, y_{0}, Z\right)
$$

where the first term is derived from the distribution of proposed wages and hours. This answers the question: Does work pay?

Such a comparison is also valid in a present value context, provided that utility when working and utility when not working are discounted using a common discount factor, $\rho$. However it ignores the time-limited nature of the intéressement scheme that temporarily reduces implicit marginal tax rates. Call $t_{I}$ the number of periods of intéressement available to a given person, $D_{I}\left(w h, y_{0}, Z\right)$ the disposable income for those periods and $D_{0}\left(w h, y_{0}, Z\right)$ disposable income thereafter. When $t_{I}>0$, we may compare the present value of disposable income computed as

$$
D\left(w h, y_{0}, Z\right)=\sum_{t=0}^{t_{I}-1} \rho^{t} D_{I}\left(w h, y_{0}, Z\right)+\sum_{t=t_{I}}^{\infty} \rho^{t} D_{0}\left(w h, y_{0}, Z\right)
$$


with

$$
D\left(0, y_{0}, Z\right)=\sum_{t=0}^{\infty} \rho^{t} D_{0}\left(0, y_{0}, Z\right)
$$

If $\pi$ is the probability that the job is lost every period, this can be further modified:

$$
\begin{aligned}
D\left(w h, y_{0}, Z\right)= & \sum_{t=0}^{t_{I}-1}((1-\pi) \rho)^{t} D_{I}\left(w h, y_{0}, Z\right) \\
& +\sum_{t=t_{I}}^{\infty}((1-\pi) \rho)^{t} D_{0}\left(w h, y_{0}, Z\right) \\
& +\sum_{t=1}^{\infty}((1+(1-\pi)(1-\rho)) \rho)^{t} \rho \pi D_{0}\left(0, y_{0}, Z\right)
\end{aligned}
$$

Our secondary focus is on the relation between disposable income and labor supply. Indeed, equation 1 can be treated as a structural labor supply equation that depends on individual preferences and observed or potential earnings. Given the discrete nature of this model, however, comparing employed individuals with different earnings would provide no information on preferences (all of them have preferred observed earnings to no earnings). In contrast to usual continuous labor supply models, ${ }^{14}$ identification of preferences in such a model thus relies on the comparison between employed and non-employed agents.

\subsection{Econometric Specification and Estimation}

We begin our discussion of the econometric specification with the estimation of the wage-hours distribution. The French guaranteed income transfer is such that a full-time job paid the hourly minimum wage raises income significantly, relative to being on welfare. Part-time work is therefore a central issue, as it is the potential source of incentive problems. For this reason, particular attention is paid to the estimation of the full distribution of proposed hours, $h^{d}$. Furthermore, the existence of a minimum wage generates

\footnotetext{
${ }^{14}$ In many continuous labor supply models, hours are supposed to be a choice variable for the individual. Hours variation conditional on wages can thus be used to gather information on preferences. In our setting hours are not chosen by the individual per se, but rather each person is faced with a take-it-or-leave-it job offer. In this context, as the wage-hours pair is set by the employer, hours variation conditional on wages is not sufficient to infer preferences.
} 
a mass point in the distribution of hourly wages that must be taken into account. These considerations imply that flexible distributional assumptions, or semi- or non-parametric estimators, are warranted.

On another hand, inferring the full unconditional distribution from the observed distribution that is conditional on selection into employment is impossible unless the distribution is parameterized. ${ }^{15}$ As we are interested in characterizing the entire distribution of gains to employment, we use mixtures of normal and logistic distributions so as to mimic observed distributions within a strictly parametric framework. ${ }^{16}$ In addition, we must take explicit account of a widespread public employment program, the Employment Solidarity Contract (Contrat emploi solidarité, or CES), that provides half-time jobs at the minimum wage with specific rules concerning top-up (intéressement) income. ${ }^{17}$ Given these considerations, we estimate the following statistical model.

A $C E S$ is proposed when

$$
X \beta_{C}+u_{C} \geq 0
$$

If a $C E S$ offer is not received, a "regular job" wage is drawn. It is paid the minimum wage, $w=\underline{w}$, if

$$
X \beta_{S}+u_{S} \geq 0
$$

Otherwise, the wage is drawn in a truncated wage distribution with density

$$
f_{w}(w \mid w>\underline{w})=f_{w}(w) / P(w>\underline{w})
$$

and the underlying density of $w$ is generalized logistic:

$$
f_{w}(w)=\frac{\exp ((m-w) / s)}{s(1+\exp ((m-w) / s))^{2}}
$$

where parameters $m$ and $s$ are estimated.

Hours worked can be drawn from a full-time distribution or a part time distribution. If

$$
X \beta_{H}+u_{H} \geq 0
$$

\footnotetext{
${ }^{15}$ This does not imply that moments of these distributions can not be estimated; see Das, Newey and Vella (2003).

${ }^{16}$ For example, we found that the distribution of log hourly wages conditional on being paid above the minimum more closely resembles a truncated generalized logistic distribution than a truncated normal distribution, while we use a probit specification - and thereby a normal distribution - to model the probability of being paid the minimum wage.

${ }^{17}$ This type of contract is not specifically considered in figures 1 and 2 .
} 
then hours is drawn from a full-time truncated distribution with density

$$
f_{1 h}(h \mid h>0, h \leq \bar{h})=f_{1 h}(h) / P(h>0, h \leq \bar{h})
$$

where $\bar{h}$ is the maximum working time. ${ }^{18}$ Otherwise, the hours worked are drawn from the part time density $f_{2 h}(h \mid h>0, h \leq \bar{h})$, defined in a similar manner. The underlying densities are also generalized logistic:

$$
f_{i h}(h)=\frac{\exp \left(\left(m_{i}-h\right) / s_{i}\right)}{s_{i}\left(1+\exp \left(\left(m_{i}-h\right) / s_{i}\right)\right)^{2}}, \quad i=1,2
$$

We set $m_{1}=169$, the standard full-time monthly hours worked and $m_{2}=87$, the standard half-time hours worked. Parameters $s_{1}$ and $s_{2}$ are estimated.

Finally, in order to account for the selectivity into employment, we assume that a reduced form to equation 1 can be approximated by

$$
\left(X, Z, D_{0}\left(0, y_{0}, Z\right)\right) \gamma+\eta \geq 0
$$

Although this linear approximation is questionable with respect to the structural interpretation of the equation, it must be clear that, at this stage, this equation is only meant to control for selectivity, using variables in $Z$ excluded from $X$.

All residuals $\left(u_{C}, u_{S}, u_{H}, \eta\right)$ are assumed to be jointly normally distributed. However, it was necessary to impose the constraints $\rho_{u_{C}, u_{S}}=0$ and $\rho_{u_{C}, u_{H}}=0$ in order to obtain convergence. The model is estimated by simulated maximum likelihood using the GHK simulator (see Hajivassiliou and Ruud, 1994). It should be noted that, because of the strong presence of $C E S$ and the important modes in the empirical hours and wage distributions at half-time work, full-time work and the hourly minimum wage, our estimation strategy focuses around these categories as well as $C E S$ while also correcting for selection bias. Unfortunately, given the limited data at hand, the underlying full-time hours, part-time hours and wage distributions (represented by generalized truncated logistic distributions) could not be conditioned on $X$ and on selection. Figures 3a-3b illustrate the performance of this statistical model. The observed distributions of wages and hours are compared with their distributions simulated from this model (conditional on employment) on the employed population. In spite of its very parametric nature, the presence of mixtures and proper accounting for truncation appear to

\footnotetext{
${ }^{18}$ As we have no a priori knowledge of the maximum monthly working time of the set of offered jobs, we used the sample maximum for each sex to define $\bar{h}$, which is the best nonparametric estimator of this parameter. For men, $\bar{h}=312$, while for women, $\bar{h}=333 \frac{2}{3}$.
} 
generate a remarkably good fit. Moreover, the observed share of employed at the minimum wage is $69.78 \%$ and the estimated share is $69.45 \%$.

In order to further investigate the link between gains to employment and observed employment, we then estimate the structural model based on equation 1. In order to take simple functional forms for utility functions, we set:

$$
U\left(D\left(w h, y_{0}, Z\right), h ; Z, \varepsilon\right)=\alpha \log D\left(w h, y_{0}, Z\right)+k(h)+Z \delta+\varepsilon
$$

when working, and:

$$
U\left(D\left(0, y_{0}, Z\right), 0 ; Z, \varepsilon\right)=\alpha \log D\left(0, y_{0}, Z\right)+k(0)+Z \delta_{0}+\varepsilon_{0}
$$

if not working. We normalize $k(0)=\delta_{0}=\varepsilon_{0}=0$ and $\operatorname{var}(\varepsilon)=1 . k(h)$ is a function to be specified. If we assume, as in van Soest (1995), that $\varepsilon$ is independent of $\left(w^{d}, h^{d} \mid X\right)$, then the contribution to the likelihood for working individuals is:

$$
\begin{aligned}
& P\left(\text { Employment at } w, h \mid X, Z, y_{0}\right)=P\left(\varepsilon \geq \alpha\left[\log D\left(0, y_{0}, Z\right)\right.\right. \\
& \left.-\log D\left(w h, y_{0}, Z\right)\right] \\
& -k(h)-Z \delta) \\
& \times f(w, h \mid X)
\end{aligned}
$$

and for non-working individuals:

$$
\begin{array}{rr}
P\left(\text { Non-Employment } \mid X, Z, y_{0}\right)=\int_{w^{d}} \int_{h^{d}} & P\left(\varepsilon<\alpha\left[\log D\left(0, y_{0}, Z\right)\right.\right. \\
& \left.-\log D\left(w^{d} h^{d}, y_{0}, Z\right)\right] \\
& \left.-k\left(h^{d}\right)-Z \delta\right) \\
& \times f\left(w^{d}, h^{d} \mid X\right) d w^{d} d h^{d}
\end{array}
$$

where the joint distribution $f\left(w^{d}, h^{d} \mid X\right)$ has been previously estimated as described above. Because of the independence assumption, the density in equation 6 can be neglected when maximizing the likelihood function. Thus conditioning on realized $(w, h)$ is possible and this would identify the model even if the $D$ functions were independent of $y_{0}$ and $Z$. This identification relies on the fact that, if $\alpha>0$, observed wages must be higher than average offered wages (where offered wages are simply identified by the exclusion of some variables in $Z$ and $y_{0}$ from the variables in $X$ in the first-step estimation). Additional identification is provided by further variation in $D$ due to factors that have no direct effect on preferences for work (such as housing allowances that depend on public or private housing sector, ownership and zones). 


\section{Data and Earnings Estimation Results}

In this section, we begin by describing the data we use for our analyses and provide some basic descriptive analysis concerning the jobs that RMI recipients obtain when they leave the RMI. We then present the results of estimating the proposed wage and hours distributions.

\subsection{The Data}

We use the Outcomes for RMI Recipients Survey (Devenir des personnes sorties du RMI, see Fougère and Rioux, 2002), which was undertaken by the French National Institute for Statistics and Economic Studies (INSEE) in collaboration with several other public institutions. A representative sample of RMI recipients was drawn and surveyed in December of 1996 and a follow-up survey was then administered one year later, in January 1998. We exploit this second cross-section which includes, along with demographic and household characteristics, information concerning the employment status of the person, in particular his or her monthly earnings and hours (if employed) as well as all of the information necessary to reconstruct the other transfers for which the household is eligible. This last point is particularly important, since the housing subsidies introduce a highly nonlinear, and sometimes discontinuous, relation between labor earnings and disposable income (see section 2); it is thus critical to be able to identify precisely the households that have access to this subsidy and to adjust their disposable income accordingly.

Residual eligibility for intéressement payments at the follow-up survey date is not directly measured. Nevertheless, it depends on the time spent working in the past months or years, according to a complex set of rules. We use activity calendars to calculate the number of hours during which each individual may still be eligible for intéressement payments as of January 1998. We were able to reconstruct this information for $87 \%$ of the sample. By construction, the remaining $13 \%$ are individuals with neither long periods of employment nor long periods of non-employment over the past year. ${ }^{19}$ When eligibility is available, we find that $72 \%$ of the population has the opportunity to benefit the RMI top-up for the full 750 hours, whereas $19 \%$ has exhausted this possibility and would get the disposable incomes drawn

\footnotetext{
${ }^{19}$ The subsamples for which residual intéressement rights can and cannot be calculated seem roughly similar on the basis of observable characteristics, and as a result we perform the majority of our analyses only on the sample for which we are able to reconstruct residual rights to intéressement payments.
} 
on the bottom lines of figures 1 and 2 . The remaining $9 \%$ is eligible, but for less than 750 hours, with residual hours distributed rather smoothly. These figures are decomposed by gender in the Appendix table.

We use the survey both to estimate the structure of wages and hours available to RMI recipients and to simulate the potential gains to employment for the entire population of RMI recipients. We restrict our attention to people between 17 and 55 years old, and we exclude students and retirees and some missing observations, which leaves us with 2,764 beneficiaries. Descriptive statistics are presented in the Appendix. We also eliminate selfemployment for the estimation of potential income. We assume 100 percent take-up of transfers for which the household is eligible in the simulations. ${ }^{20}$ This provides us with a lower bound on the gains from employment. In order to avoid the complicated issue of simultaneous labor supply decision making within households, couples are excluded from the sample when we examine the link between gains to employment and observed employment. ${ }^{21}$

The data is also subject to measurement error with respect to reported earnings and hours. Monthly earnings as well as usual weekly hours are recorded by the survey. It appears that a significant portion (roughly one third) of the hourly wage rates computed from this information lie below the minimum wage. Most of these inconsistencies are obviously due to rounding errors and the fact that relatively few individuals in the sample are paid above from the minimum wage in this population. Thus, whenever reported hourly wages fall below the minimum wage, we assume that monthly earnings are more reliable than monthly hours, set the hourly wage to the minimum wage and recompute hours based on reported monthly earnings so as to be compatible with existing minimum wage laws.

\subsection{Realized Outcomes of the RMI Recipient Population}

Before considering potential gains to employment for the RMI recipient population, it is useful to analyze the realized outcomes for those actually employed at a point in time. Of the initial December 1996 sample, one-third are employed a year later, only $10 \%$ of whom are in self-employment. Among those in employment, $33 \%$ are employed under the CES public employment program. These jobs are half-time jobs paid at the minimum wage and they

\footnotetext{
${ }^{20}$ Our data do not contain sufficient information to measure take-up rates accurately. See Gilles-Simon and Legros (1996) and Terracol (2003) for analyses of benefit take-up in France.

${ }^{21}$ Individuals in couples do, however, contribute to the estimation of the wage and hours offer distributions.
} 
represent an important aspect of the government's active labor market policies. Zoyem (1999) shows that this sort of contract is frequently proposed to RMI recipients, and is occasionally incorporated into an individual's "reinsertion contract". ${ }^{22}$

Figures $4 \mathrm{a}$ and $4 \mathrm{~b}$ report observed monthly earnings (wage rate times hours worked, gross of any transfers). They make clear that the earnings of RMI recipients, once reemployed, are low and concentrated around the halftime and full-time minimum wage. The strong bimodal distribution is very unusual for the male population. It is also clear that active labor market policy, in the form of $C E S$ jobs, plays an important role in this phenomenon. This reinforces the justification for the specification described in section 3.2, in particular equation 2. It also suggests that the gains to employment might be cyclically sensitive as well as dependent on the attitude of policy makers toward active labor market policy.

\subsection{Estimation Results}

The results of estimating the reduced form models described in section 3 are presented in table 1 . The models were estimated separately for men and women. All continuous variables used in the estimation are standardized to be mean 0 and to have a unit standard deviation, implying that the coefficients are interpretable as the effect of a single standard deviation change in the corresponding variables.

As the correlation coefficients between the selection equation and the various other models make clear, selection bias is an issue for men in the $C E S$ equation ${ }^{23}$ and for women in the minimum wage and working time models. Our specification includes education as a set of indicator variables corresponding to the highest degree obtained (the reference is primary education), a quadratic specification in age, an indicator variable for French nationality and another for living in the Paris region. Disposable income on welfare, and demographics are included only into the selection equation. Overall, the explanatory power of the observed variables in our model seems limited, and this is likely related to the fact that we study a relatively homogenous population, at least in terms of their labor market prospects.

\footnotetext{
${ }^{22}$ Reinsertion contracts are programs negotiated between the RMI recipient and his or her caseworker, intended to help the RMI recipient plan his or her transition from welfare back into work (Zoyem, 1999).

${ }^{23}$ The tendency of the estimated parameter to head toward the upper bound suggests that this correlation coefficient may be poorly identified. However, this appears to be primarily a sampling issue (and not a case of the parameter being fundamentally unidentifiable), since the same parameter for women behaves much more reasonably.
} 
Commenting on the selection equations, it is clear that the probability of employment increases with education for both sexes, with the significant coefficient on education category 4 reflecting the technical or professional nature of this type of education. Having children, especially young children, reduces the chance of a female welfare recipient in 1996 being employed in 1998, although the effect does not appear relevant (and is even reversed for the oldest children) for men. Women in couples and widows are much less likely to be employed than women who have never been married (conditional on age), whereas men in couples are significantly more likely to be observed in employment relative to never married men. The profile of employment with respect to age is not significantly different from flat for women, whereas the probability of employment decreases with age for men who received RMI benefits in 1996, at least initially. The full profile is convex, but not significantly so.

It is interesting to note that the reduced form coefficients on disposable income from welfare $\left(D\left(0, y_{0}, Z\right)\right)$ are generally positive, and significantly so for women. This implies that additional income provided by the RMI may not reduce, and may actually be associated with an increase in the probability of an individual being observed in employment. That said, the model outlined in section 3.1 has no implication on the sign of this effect, because $D\left(0, y_{0}, Z\right)$ is generally correlated with $D\left(w h, y_{0}, Z\right)$ and it is the difference between the two that is relevant for job acceptance.

We turn next to the equations describing the probability of drawing a $C E S$. Table 1 suggests that such jobs are less common in the Paris region than elsewhere in France, and that the probability that a woman draws a $C E S$ is concave in her age. The correlation coefficients suggest, especially for men, that the unobserved events that make a person likely to be employed also increase the chances that the job will be a CES.

Considering the wage and working time models, it appears that the probability that a female welfare recipient will draw a minimum wage job decreases initially with age, then increases later as the profile is convex. Furthermore, the most educated workers are significantly less likely to draw a minimum wage job in the event that they do not otherwise get one through a $C E S$, for both men and women. Education does not, however, seem to be significantly related to the probability of drawing a full-time job for men or women. Full-time jobs are significantly over-represented among women living in the Paris region, however. Given that much of the dispersion in male working time is due simply to the nature of the job (CES or non-CES) (figure $4 \mathrm{~b}$ ), one does not expect the men's working time equation to perform particularly well. 
The remaining correlation coefficients are only significant for women, and these are only significant at the $10 \%$ level. Still, the signs are negative for both men and women on the correlation between the minimum wage and full time employment equations, suggesting that non-CES minimum wage jobs are also more often part-time than full-time. There is also a negative correlation for both men and women between the disturbances of the employment and minimum wage equations, suggesting that those people more likely to be seen in work are also less likely to draw a minimum wage job when they are not offered a $C E S$.

\section{The Gains to Employment}

We use the results presented in table 1 to assign disposable income for each household in the full (representative) sample. To do this, we draw wage rates and working hours from their estimated distributions, unconditional on employment status (this applies to everyone, whether employed or not). ${ }^{24}$ Figures $5 \mathrm{a}$ and $5 \mathrm{~b}$ illustrate the distributions of hours thus generated (the dashed lines, labeled "Estimated"). Hours are extremely concentrated around half-time work, especially for women, but also for men. Also, more than $80 \%$ of simulated jobs are paid the minimum wage. In the context of the model outlined in section 3.1, these can be interpreted as the offered wage-hours combinations this population might receive, noted $\left(w^{d}, h^{d} \mid X\right)$ above.

Given each household's simulated labor earnings, we apply the system of taxes and transfers present in France in 1998 and described in section 2, to obtain a measure of disposable income while employed. We consider 3 alternative scenarios.

1. A baseline scenario: the intéressement top-up is computed for those who are eligible until their eligibility runs out, then the individual is subject to the regular earnings environment (including the RMI minimum income guarantee) forever;

2. A comparison scenario for evaluating the importance of intéressement: the job is held forever but everyone is assumed to have exhausted their intéressement eligibility; ${ }^{25}$

\footnotetext{
${ }^{24}$ We draw 20 unconditional wage-hours pairs per observation (generating 55,280 points) based on the full econometric model in order to obtain a smoother view of the overall distribution.

${ }^{25}$ This scenario excludes intéressement payments for "regular jobs", although it applies
} 
3. A comparison scenario for evaluating the importance of job loss: job loss occurs with a fixed probability every month and intéressement payments are computed for those who are eligible until their eligibility runs out (unless they lose their job first), then the individual is subject to the regular earnings environment (including the RMI minimum income guarantee) until the job is lost. When a job is lost, the individual returns to the RMI program forever. ${ }^{26}$

The first scenario is the baseline because it simply compares the monetary value of a job with the value of welfare. This is comparable to what is done in the "making work pay" literature. The last scenario can be seen as a lower bound to the gains because the possibility of job-loss decreases the value of employment, whereas the value of non-employment does not take into account the event that new labor earnings can be available in the future. Under each scenario, we compute the present value of earnings as explained in section 3.2 (to account for changes of income flows over time due to the intéressement rules) and convert it to a constant monthly flow. ${ }^{27} \mathrm{In}$ the case of individuals living in couples, we assume that the spouse/partner provides no additional labor income. ${ }^{28}$ This is compared to the monthly flow of disposable income from the RMI (i.e. assuming no one works) in order to calculate the gain to employment. Table 2 describes the distribution of these gains for different household types and under the different scenarios. Figures $6 \mathrm{a}-6 \mathrm{c}$ trace some of the distributions of gains for the baseline scenario (singles only).

Our estimates suggest that almost every household gains from work in the baseline case. This is because the $100 \%$ tax rate only applies in a very particular circumstance: the household has exhausted its entitlement to intéressement, it does not get a $C E S$ job and earnings are below those of a half-time minimum wage job (approximately). This combination happens

the appropriate legislation in attributing top-up payments to any individual employed on a $C E S$ because they are not subject to exhaustion and these payments are simply part of the $C E S$ scheme.

${ }^{26}$ We use the empirically observed monthly rates of transition out of regular and $C E S$ employment toward non-employment. Based on the activity calendars, these correspond to 0.0589104 and 0.0560717 respectively.

${ }^{27}$ We apply a monthly discount factor of 0.995 , which is equivalent to an annual interest rate of roughly $6 \%$

${ }^{28}$ The question of the joint labor supply decision is beyond the scope of this paper. This assumption implies that we are calculating a lower bound of the gains to employment for couples, although much of our subsequent analysis will focus on singles. Gurgand and Margolis (2000) examine the implications of relaxing this hypothesis, but in the absence of intéressement. 
rarely. On the hand, the value of the estimated monetary gains are small. For comparability between household types, gains are computed either per adult equivalent or as a percentage increase over welfare income. The highest gains are for single persons, and even then the median gain is only 103.70 euros per month. For single parents or couples, median gains are only 30 to 70 euros per person. It should also be noted that the large difference between mean and median gains suggests a very skewed distribution of gains, with a large probability mass at low levels (driven by $C E S$ jobs) and several higher gains that serve to pull the mean upwards: this is confirmed by figures 6a6c. Figure $6 \mathrm{c}$ also shows a small mode for men around full-time work. For women, the distribution is multimodal because of the impact of the number of children (compare figures $6 \mathrm{a}$ and $6 \mathrm{~b}$ ). In line with figure 5a, full-time work generates only a very slight mode for women.

The results for women, especially single mothers, are particularly worrisome and are due to a combination of factors. These women are found in the lower tails of the distributions of wage rates and hours and they are subject to high implicit tax rates through the means-testing of family benefits. These small monetary gains would likely result in a net loss to single mothers when child care costs (not measured here) are added in. The French transfer system includes a special program to subsidize child care, while schooling is free from age 3. But it is unlikely that this assistance at the margin would be a sufficient complement to the very small estimated potential gains to employment.

Comparing the baseline to the simulation without intéressement, it appears that the contribution of the interessement scheme to the distribution of gains is very limited. Intéressement mechanically ensures that $13 \%$ additional beneficiaries will have a strictly positive gain from working (increasing the percentage with gains from $86 \%$ to $99 \%$ ), but there is practically no visible difference in the amounts of the gains to employment. One reason is that the $13 \%$ marginal beneficiaries are among the lowest paid, and as such they contribute small gains.

The other reason for the apparently minor impact of the suppression of the interressement scheme is that the amount of additional gains provided by intéressement is limited on average. Recall that, in this simulation, the suppression of intéressement payments does not concern CES jobs, as they are subject to a separate set of rules. ${ }^{29}$ In addition, the changes relative to the baseline case do not apply to observations with household income

\footnotetext{
${ }^{29}$ This is the reason why the median values, which are primarily driven by the prevalence of $C E S$ jobs, remain unaffected.
} 
above twice the RMI threshold (because then eligibility to both RMI and intéressement is lost), while the top-up only corresponds to $50 \%$ of a small amount when wages are small enough to benefit from the intéressement scheme. Finally, since the top-up is only available for a limited amount of time (750 hours of work or less), the present value of the corresponding "wealth" is only marginally affected by the periods during which the top-up is available, even if one applies a high discount factor. Overall, the features of the intéressement system, especially its time-limited nature, seem to imply that it may have a very small potential to affect incentives to work despite the relatively large kinks in the disposable income profiles (see figure 2). This is probably one of the reasons why the rules governing the intéressement scheme were modified in 1998 and 2001 so as to extend its applicability from 750 hours to about one year and reduce the implicit marginal tax rate from $50 \%$ to $0 \%$ during the first three months.

Accounting for the possibility of job-loss in scenario 3 leads to a quantitatively different picture than the more static comparison of the previous scenarios. Allowing for a job termination probability of 5-6\% every month reduces the gains to employment substantially. Although this simulation can be viewed as a lower bound, the highly unstable nature of the jobs available to this specific population make this simulation informative. This also suggests that a dynamic model which would allow transitions to and from employment should be developed, but formalizing such a structural model is complicated by the highly non-stationary nature of the rules governing the intéressement scheme. Although stylized, the relatively straightforward scenarios presented here are useful for gaining intuition about possible labor supply incentive effects inherent in the system.

\section{The Relation Between Gains to Work and Em- ployment}

The discussion thus far has been centered on the gains to employment for the entire (representative) population of RMI recipients. However, the possible monetary incentive effects on labor supply of the RMI, insofar as they have behavioral consequences, should be visible when comparing the simulated gains of people actually observed in employment with those of people not observed employed. In particular, equation 1 implies that those observed in employment may tend to have larger gains to employment than comparable workers not observed in employment. 


\subsection{Gains to Employment and Observed Employment Status}

Figures 5a and 5b compare three distributions of hours. Unconditional (on employment status) distributions are simulated for the employed and the non-employed populations (dashed lines). This describes the ex ante incentives that are faced by each population and depends only on structural differences in terms of observable characteristics. It is clear that the population that was indeed observed employed has access to longer working times. Moreover, the simulated likelihood that women are offered only the minimum wage is $82 \%$ in the employed population and $87 \%$ among the unemployed; these figures are $81 \%$ and $85 \%$ respectively for men. ${ }^{30}$ Given that people can only choose to accept or reject the jobs that may be proposed to them, observed wages and hours among the employed population are again different from jobs offered to that population. This is, strictly speaking, the selection effect, drawn in solid line on the figures. For both men and women, observed hours are more often around full-time, with clearly higher wages: ${ }^{31} 74 \%$ of women do work for the minimum wage (to be compared to the simulated $82 \%$ offered in the same population); the figure is $66 \%$ for men (to be compared with the simulated 81\%). Both composition and selection effects combine to generate very different pictures of the employed and non-employed populations.

Table 3 decomposes the corresponding distributions of gains to employment under the baseline scenario. Although it is clear that a smaller share of individuals among the population actually observed in employment has positive simulated gains, ${ }^{32}$ it is also evident that the value of these gains are, on average, larger. This is true for almost all cells in the table. Furthermore, expressed in terms of gains, the selection effect seems very large. An important point to note is that this occurs because accepted jobs not only involve a higher wage rate but also a longer working time. With more than $80 \%$ of proposed jobs at the minimum wage, working time becomes an important adjustment variable. It seems that welfare beneficiaries, when working, would rather work longer hours in order to increase their gains.

\footnotetext{
${ }^{30} \mathrm{By}$ construction, the distributions of wages above the minimum wage are identical in our statistical model.

${ }^{31}$ The figures draw marginal distributions, but the correlations estimated in table 1 imply that the effect of wages reinforces that of hours, i.e. a lower probability of a minimum wage job is associated with a higher probability of full-time employment.

${ }^{32}$ This is because the entitlement to intéressement in the non-employed population tends to be larger, by construction.
} 


\subsection{Structural labor supply estimation}

In order to provide a more structured depiction of the above presentation of gains by employment status, we estimate the structural employment model defined by equations 6 and 7. Because of data limitations, we were forced to adopt a very simple specification. For women, the only control variables in the $Z$ vector are age and the number of children in three age classes. For men, only age is maintained because the number of children appeared irrelevant. We adopted 2 very simple functional forms for $k(h): \log (h)$ or a dummy variable for more than 130 monthly hours. The potential gains (expressed in logarithms) are computed using the baseline scenario. The model is estimated by simulated maximum likelihood, using 500 draws to estimate the joint distribution of $\left(w^{d}, h^{d} \mid X\right)$ in the evaluation of the double integral in equation 7 and assuming a standard normal distribution for $\varepsilon{ }^{33}$

To avoid the complexities related to joint labor market decisions, table 4 presents the results of estimating this employment model on singleadult households only ( $70 \%$ of the sample). Although the model specification is reduced to its basics, our estimation presents some interesting results. As expected from the above discussion, the income and hours variables have a significant influence on employment probability, although their respective impact is difficult to distinguish. The coefficient on disposable income ( $\alpha$ in equations 6 and 7 ) is high and precisely estimated in the absence of the hours variable. It implies that a $10 \%$ increase in the ratio $D\left(w h, y_{0}, Z\right) / D\left(0, y_{0}, Z\right)$ would result in a $11 \%$ average increase in employment probability for both men and women in the population. When working time is included, however, the estimated $\alpha$ shrinks dramatically and is not always significant. Indeed, hours alone explain $89 \%$ of the variance in gains for men and $78 \%$ for women, so that collinearity is an issue. When testing the joint significance of disposable income and hours, despite the fact that the effects of the two variables are hard to distinguish precisely, their joint significance is very large (recall that the $99 \%$ confidence level for $\chi^{2}$ is 9.21). ${ }^{34}$

Whether measured as a continuous variable or with a dummy, both men and women are more likely to accept jobs that offer more hours of work. These results are compatible with estimates obtained by Laroque and

\footnotetext{
${ }^{33}$ Note that the standard errors reported in this table are not corrected for the presence of estimated regressors, notably the gains to employment and the hours offer for people not observed in employment.

${ }^{34}$ When the age variable is not present, there is less collinearity and the results are more precise, but for a priori labor supply considerations we hesitate to adopt such a specification.
} 
Salanié (2002) for the whole French female population. In their context, there is much more variation in the wage rate, so that collinearity is less of an issue.

Finally, older beneficiaries are less likely to be observed working in 1998 . This result is robust and very precisely estimated. Women with young children also work less and this effect is also strong: one more child aged below 3 would decrease the probability of a single woman being employed by $90 \%$ on average. As noted above, this is consistent with the idea that the very low gains that single women can expect from employment, coupled with the likely high costs of caring for small children, can render negative the net return to working for a single mother with small children.

\subsection{Discussion}

Overall, these structural estimates suggest that monetary incentives have non-negligible effects on labor supply in this population. Although potential gains from working are small on average for the whole population, welfare beneficiaries are observed working when earnings are higher than the typical earnings accessible. Those two considerations imply that there is scope for improving incentives.

It must be noted that this is a strict labor supply interpretation of the basic facts presented in the previous sections. In the theoretical model, we do not allow the possibility that job offers may not be proposed at all to some of the welfare beneficiaries. It could be argued that individual with more productive characteristics are also more likely to receive offers. In our specification, the negative values of the intercept (table 4) are taken to mean that no work is preferred to some work. If a probability that a job is offered at all was added to the model, it would be identified separately from this intercept under strong conditions ${ }^{35}$ that would not be empirically relevant in our data. Our implicit assumption is rather that a job can always be found (and represented by a draw from the distribution $\left(w^{d}, h^{d} \mid X\right)$ ), but that the offer may be so unattractive that most individuals would be reluctant to take it. Such an assumption is compatible with sociological field analysis of this population (Benarrosh, 2003).

In this context, the central hypothesis for the structural model is independence between preferences and proposed earnings. Given the limited impact of observed characteristics that are usually strong determinants of wages in the earnings equations (table 1), we believe it is unlikely that some

\footnotetext{
${ }^{35}$ Laroque and Salanié (2002) use an "ad infinitum" type of reasoning to justify their identification of the probability of receiving a job offer.
} 
unobserved individual-specific characteristic related to the relative taste for work could have a strong and systematic effect on offered wages. We are thus confident that at least some of the difference between potential and observed wages can be attributed to labor supply effects.

A direct consequence of this independence hypothesis is that selectivity in the wage equations is not interpreted as arising from individual unobserved characteristics, but rather from sorting into the most satisfactory job offer. This is the reason why jobs are drawn unconditionally (on employment status) in the simulations. Were we to interpret selection effects as being due to unobserved individual characteristics, the non-employed population would have even lower simulated earnings. Because the non-employed are a majority, this would put even more weight on lower potential gains from working in the overall distribution.

Finally, note that our likelihood function implicitly assumes that welfare beneficiaries only make one draw from the job offer distribution which they may take or leave. This is very much in line with the static approach to labor supply. In contrast, Dickens and Lundberg (1993) allow workers to choose among a random number of offers. In such a context, those who had the opportunity to choose between a larger number of alternatives would select jobs with higher earnings and would therefore be more often observed in employment. However, for the purpose of estimating the sensitivity of preferences to disposable income, assuming (1) that some people have a chance to draw a high wage or assuming (2) that some people have a chance to make a large number of draws, among which there is more often a high wage, are functionally equivalent.

\section{Conclusion}

The evaluation of potential labor earnings for recipients of a guaranteed minimum income transfer (such as the French RMI system) is a conceptually and technically delicate exercise. It remains, nevertheless, an indispensable piece of information in the debate concerning the incentive effects on labor supply of welfare. Simulations for "representative households" and calculations based exclusively on estimated effective marginal tax rates are inadequate, in that they do not account for the heterogeneity in labor market conditions that RMI recipients face. In this paper, we have considered the interaction between the labor market and the system of taxes and transfers in effect in France in 1998 (with the exception of local taxes and local transfers) accounting for the presence of the supplemental earnings top-up provided by 
the welfare system under the name of intéressement. Since RMI recipients tend to be very different from the population as a whole in terms of their reemployment labor earnings, it is important to use an RMI-centered survey to obtain reasonable sample sizes of the population of interest. But since the sorts of jobs to which RMI recipients can aspire tend to be rather particular, most notably due to the predominance of active labor market programs (such as France's CES jobs), it becomes essential to specify a model to predict wage and hours offers that fits the observed data on welfare recipients as well as possible.

We find that almost all welfare beneficiaries would gain from being employed on a job randomly drawn from the distribution of job offers, relative to staying on welfare. But the size of the gains is extremely small and is sensitive to the manner by which the gains are constructed, in particular how one treats the risk of job-loss. As of 1998, the intéressement scheme provided only marginal additional incentives. Most strikingly, the monetary work incentives for single mothers are very limited. Were we able to directly integrate child care costs and locally available means-tested assistance policies, we would almost surely find a net loss associated with work for French single mothers.

We find that the distribution of gains that we estimate for the population of individuals actually observed in employment differs from that of those individuals observed out of employment at the time of the follow-up survey. We interpret this as a labor supply effect and quantify it based on a simple structural employment model, although some of our point estimates are imprecise, in part due to the high degree of collinearity between disposable income and hours worked. The structural model is based on assumptions that make its estimation feasible with the limited data at hand. As such, our results should not be over interpreted. Nevertheless, the general impression given by the presence of both limited potential monetary gains and relatively high sensitivity of employment to gains indicates that there is likely to be some scope for improving incentives for labor supply in the French system. 


\section{Bibliography}

Benarrosh, Yolande (2003), "Les trappes d'inactivité - Chômage volontaire ou chômage de résistance ?", Travail et emploi, no 95.

CNAF (1996a), 1996, statistiques CAF et tous régimes, Série "Prestations familiales".

CNAF (1996b), Revenu minimum d'insertion au 31 décembre 1996, Série "Recherche, prévision, statistique".

Das, Mitali, Whitney Newey and Francis Vella (2003), "Nonparametric Estimation of Sample Selection Models," Review of Economic Studies, vol. 70, no. 1, 33-58.

Dickens, William and Shelly Lundberg (1993), "Hours Restrictions and Labor Supply", International Economic Review, vol. 34, 169-192.

Euwals, Rob and Arthur van Soest (1999), "Desired and Actual Labor Supply of Unmarried Men and Women in the Netherlands", Labour Economics, vol. 6, 95-118.

Fougère, Denis and Laurence Rioux (2002), "Le RMI treize ans après: entre redistribution et incitations", Economie et statistique, no. 346-347, 2001-6/7, 3-12.

Gautié, Jérôme and Alain Gubian (2000), "Réforme du revenu minimum d'insertion et marché du travail," Droit social, no. 7-8, juillet-août 2000, 699-707.

Gilles-Simon, Marie-Odile and Michel Legros (1996), "Le non-recours chez les plus pauvres: une approche empirique", Recherches et prévision, no. 43 , pp. $51-58$.

Gurgand, Marc and David N. Margolis (2000), "Minima sociaux et revenus du travail en France," Document de travail 2000-62, CREST, INSEE.

Hajivassiliou, Vassilis and Paul Ruud (1994), "Classical Estimation Methods for LDV Models using Simulation", Handbook of Econometrics, vol. 4, (Amsterdam: North-Holland).

Heckman, James J. (1979), "Sample selection bias as a specification error," Econometrica, vol. 47, pp. 153-161.

Join-Lambert, Marie-Thérèse (1998), Chômage: mesures d'urgence et minima sociaux, (Paris: La Documentation française).

Laroque, Guy and Bernard Salanié (1999), "Prélèvements et transferts sociaux : une analyse descriptive des incitations financières au travail," Economie et statistique, no. 328, 1999-8, 3-19.

Laroque, Guy and Bernard Salanié (2000), "Une décomposition du nonemploi en France", Economie et statistique, no. 331, 2000-1, 47-66. 
Laroque, Guy and Bernard Salanié (2002), Institutions et emploi: Les femmes et le marché du travail en France, CREST mimeo, Paris.

L'Horty, Yannick and Denis Anne (2002), "Transferts sociaux locaux et retour à l'emploi," Economie et statistique, no 357-358, 2002, 42-71.

Lhommeau, Bertrand (2002), "Les configurations familiales des ménages comptant un allocataire du RMI : du foyer RMI au ménage INSEE," Economie et statistique.

Liaisons sociales (1998), Barême social périodique, January 1998.

Margolis, David N. (1996), "Cohort Effects and Returns to Seniority in France," Annales d'Economie et de Statistique, January/June.

Moffit, Robert (2002), "Welfare Programs and Labor Supply", NBER Working Paper no. 9168.

Moffit, Robert (2003), "The Negative Income Tax and the Evolution of U.S. Welfare Policy", NBER Working Paper no. 9751.

OECD (2003), Employment Outlook: 2003 Edition: Towards More and Better Jobs, OECD, Paris.

Padieu, C. (1997), "RMI et Smic: étude sur l'apport financier de l'accès à l'emploi par types de ménages", Les Cahiers de l'ODAS, mars.

Saez, Emmanuel (2002), "Optimal Income Transfer Programs: Intensive versus Extensive Labor Supply Responses," Quarterly Journal of Economics, vol. 117, 1039-1073.

Terracol, Antoine (2003), Essais sur la perception des minima sociaux en France, Ph.D. Dissertation, Université Paris 1 Panthéon-Sorbonne, Paris, France.

van Soest, Arthur, (1995), "Structural Models of Family Labor Supply. A Discrete Choice Approach", Journal of Human Resources, vol. 30, no 1, 63-88.

Zoyem, Jean-Paul (1999), "Contrat d'insertion et sortie du RMI", Document de travail G 9909, Direction des études et synthèses économiques, INSEE. 


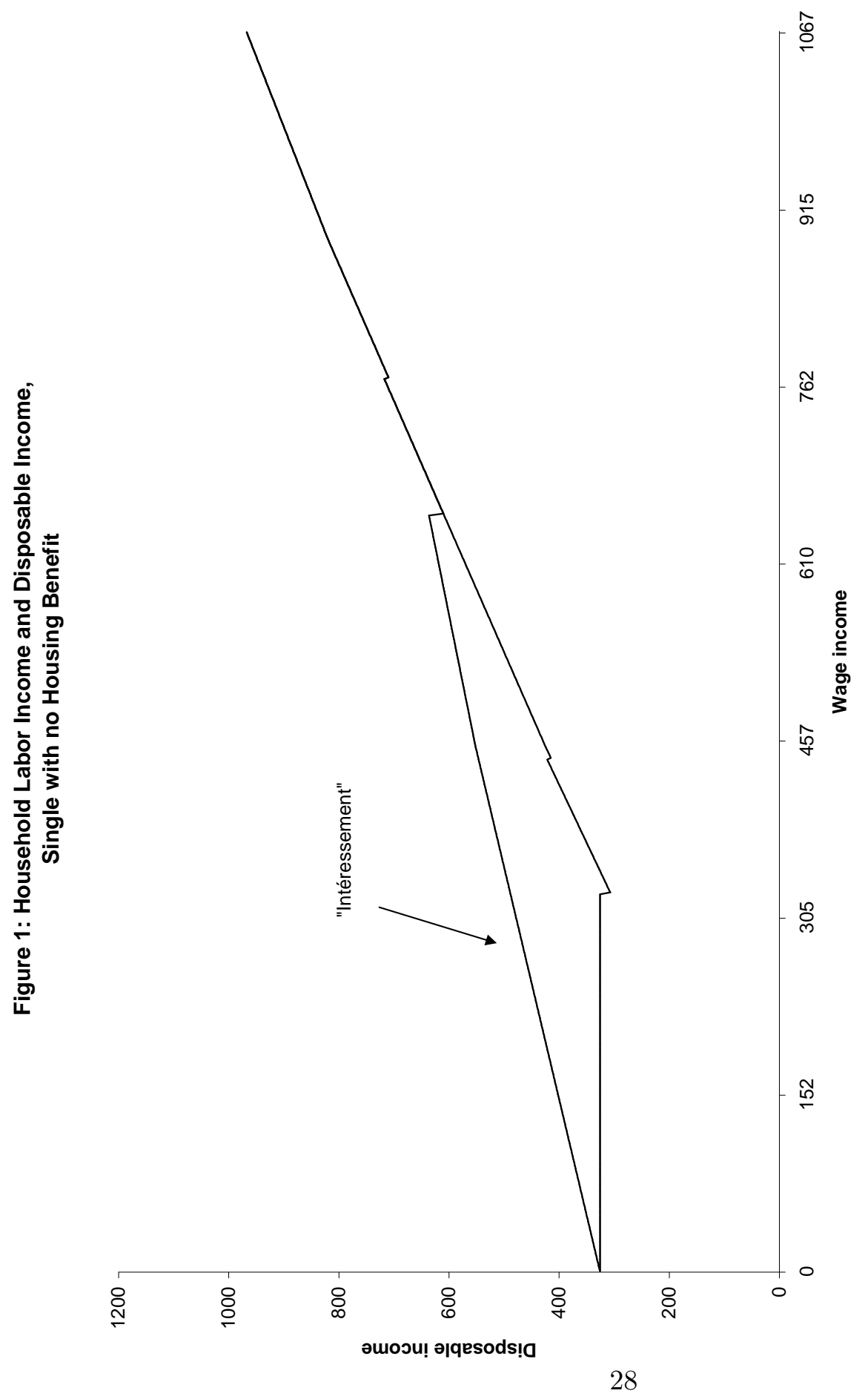




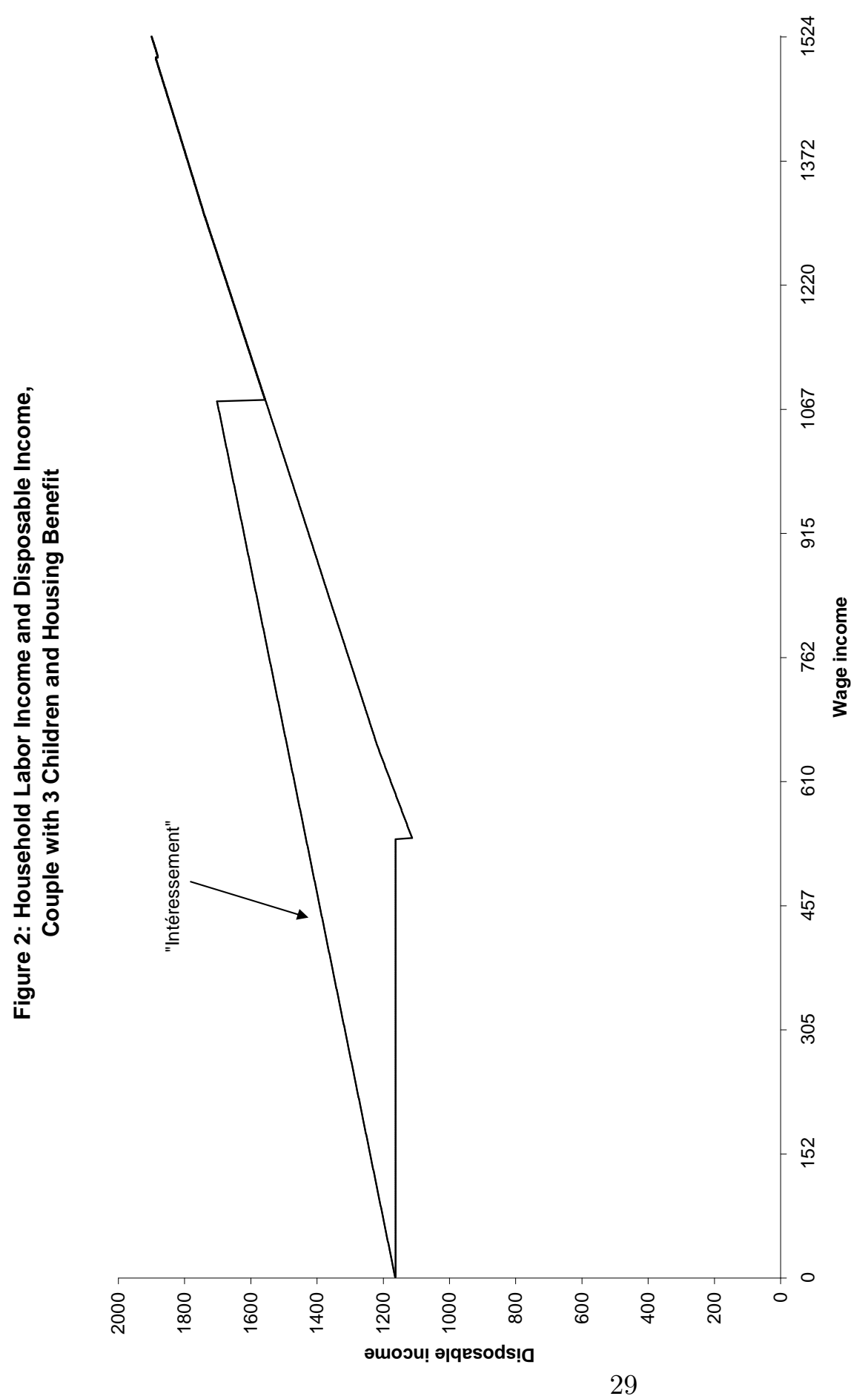



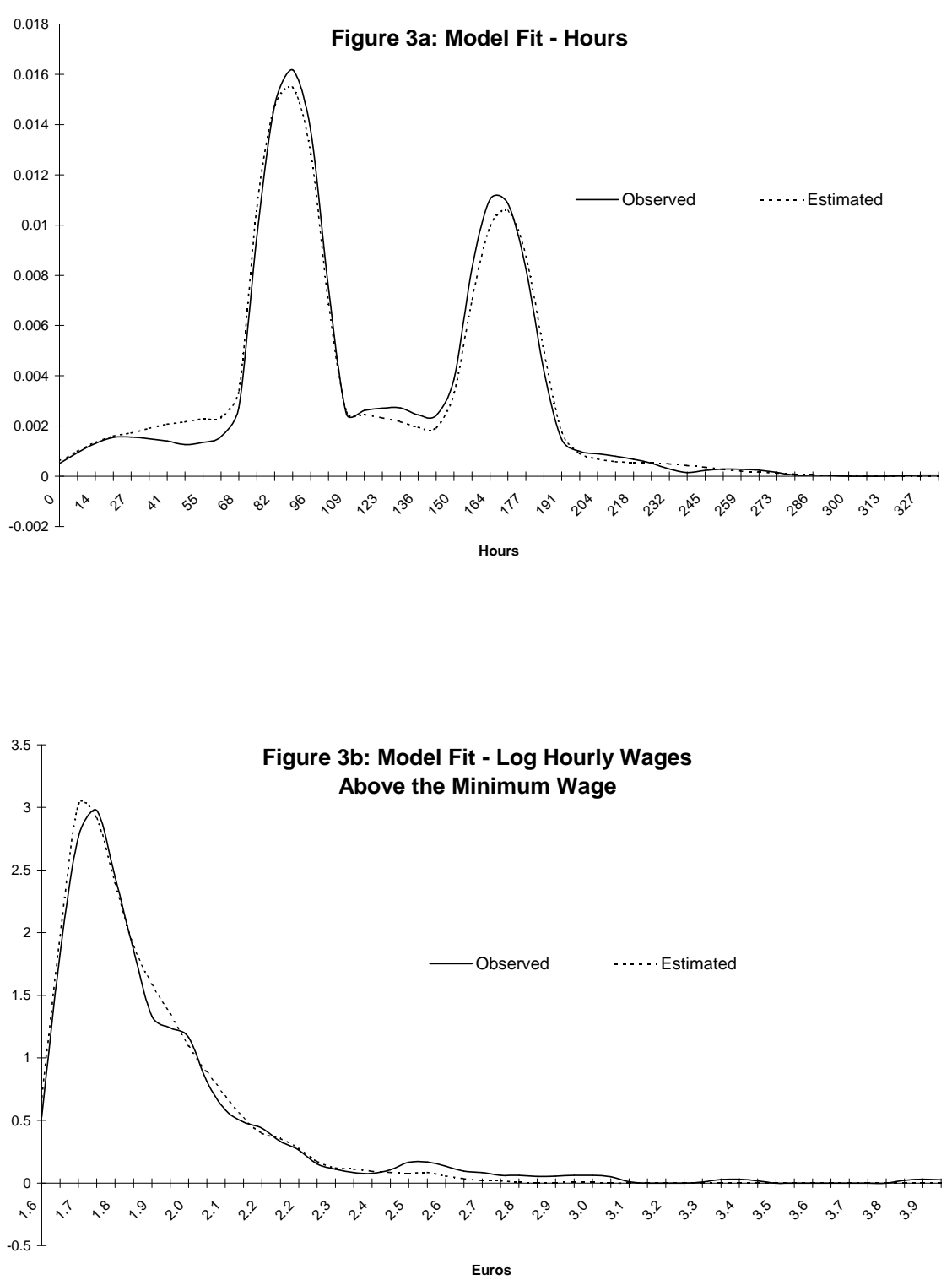

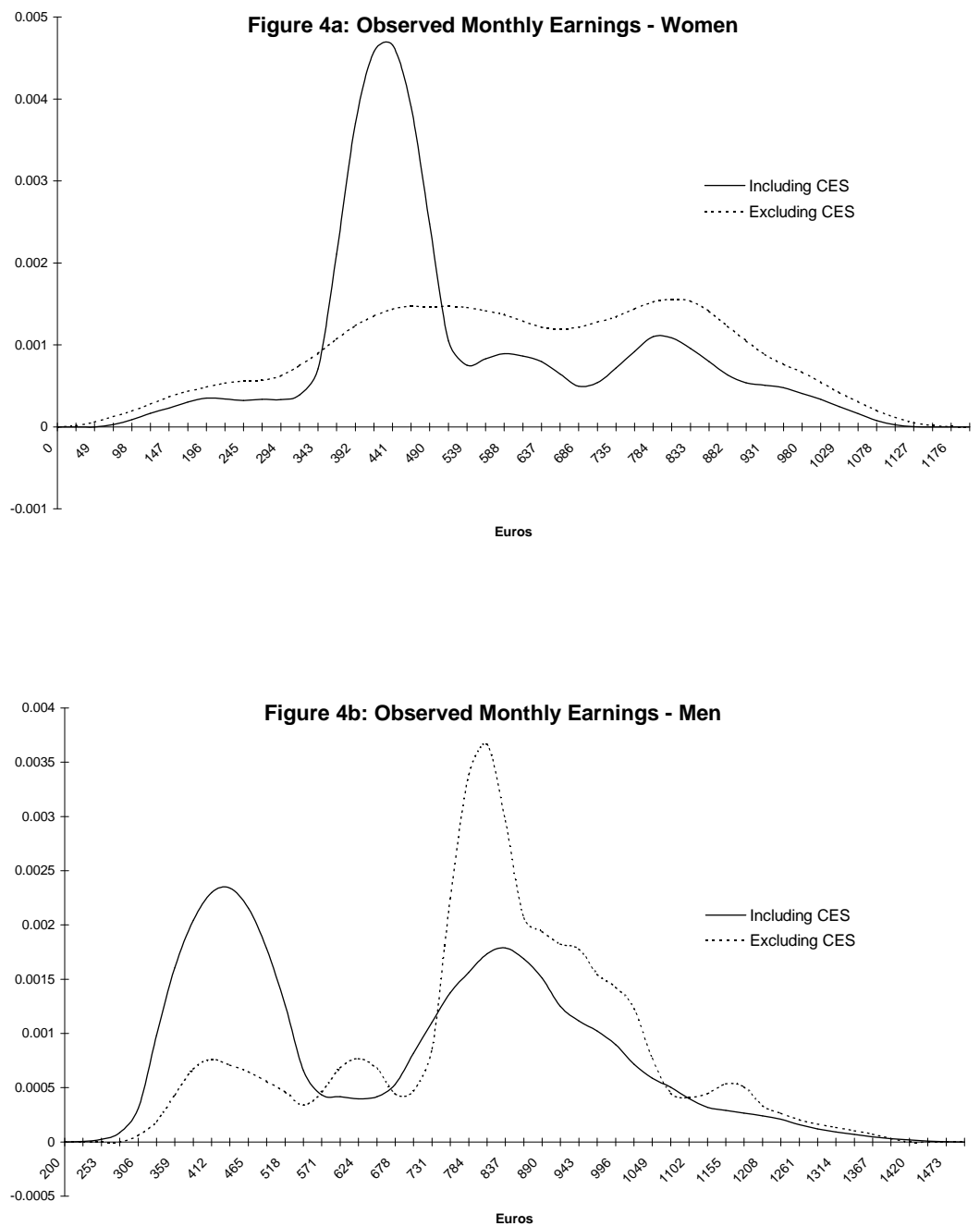

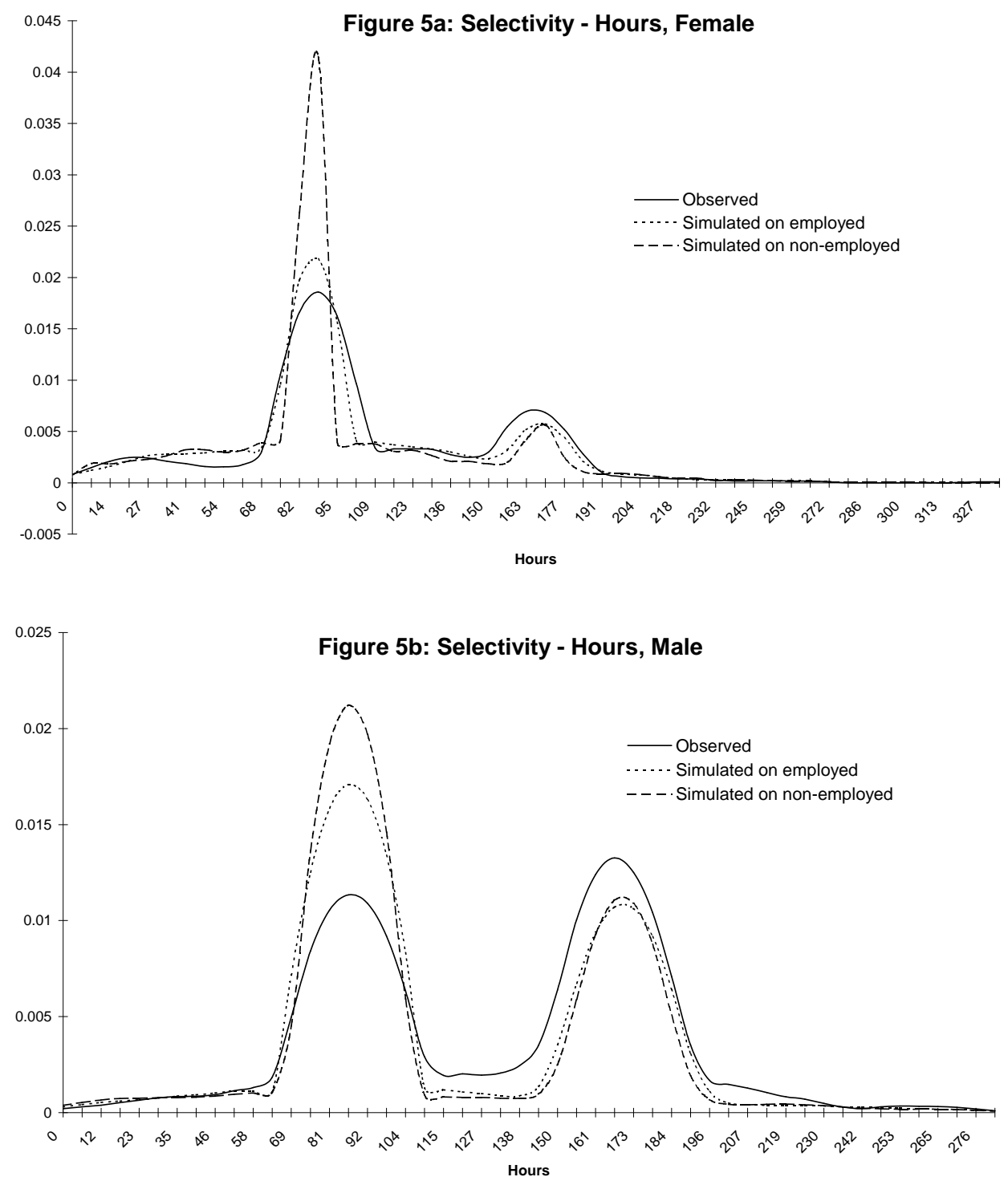

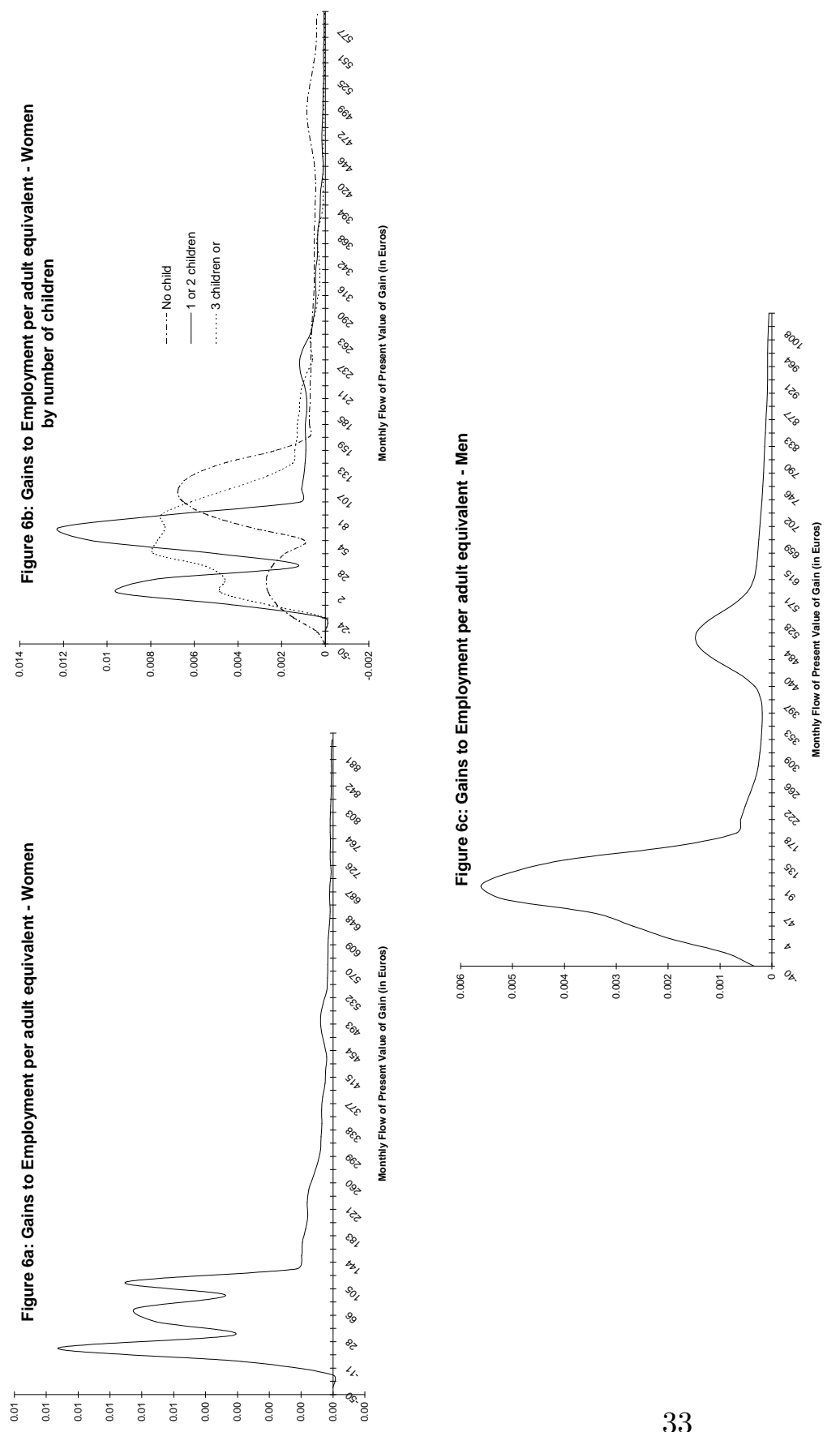
Table 1 : Results of Selection-Corrected CES and Wage - Working Time Models

\begin{tabular}{|c|c|c|c|c|c|c|c|c|}
\hline \multicolumn{9}{|c|}{ Men } \\
\hline & Selection & & CES & & Wage & & Working tim & \\
\hline Intercept & $\begin{array}{l}-0.7140 \\
(0.1358)\end{array}$ & **** & $\begin{array}{l}-1.1522 \\
(0.1256)\end{array}$ & *** & $\begin{array}{c}1.0296 \\
(0.4426)\end{array}$ & $* *$ & $\begin{array}{c}0.4126 \\
(0.6342)\end{array}$ & \\
\hline Age & $\begin{array}{l}-0.8298 \\
(0.4046)\end{array}$ & $* *$ & $\begin{array}{l}-0.2377 \\
(0.4330)\end{array}$ & & $\begin{array}{c}0.1595 \\
(0.8186)\end{array}$ & & $\begin{array}{l}-1.2293 \\
(0.9280)\end{array}$ & \\
\hline $\mathrm{Age}^{2}$ & $\begin{array}{c}0.5179 \\
(0.4093)\end{array}$ & & $\begin{array}{c}0.0733 \\
(0.4369)\end{array}$ & & $\begin{array}{l}-0.1164 \\
(0.8226)\end{array}$ & & $\begin{array}{c}1.2283 \\
(0.9378)\end{array}$ & \\
\hline French Nationality & $\begin{array}{l}-0.0811 \\
(0.1148)\end{array}$ & & $\begin{array}{l}-0.1623 \\
(0.1258)\end{array}$ & & $\begin{array}{l}-0.3367 \\
(0.2609)\end{array}$ & & $\begin{array}{l}-0.1594 \\
(0.3015)\end{array}$ & \\
\hline Paris Region & $\begin{array}{l}-0.1829 \\
(0.1161)\end{array}$ & & $\begin{array}{l}-0.5570 \\
(0.1747)\end{array}$ & **** & $\begin{array}{l}-0.2518 \\
(0.2773)\end{array}$ & & $\begin{array}{c}0.2077 \\
(0.2714)\end{array}$ & \\
\hline Education Category 1 (higher) & $\begin{array}{c}0.6280 \\
(0.1424)\end{array}$ & *** & $\begin{array}{l}-0.1067 \\
(0.1811)\end{array}$ & & $\begin{array}{l}-0.6378 \\
(0.3285)\end{array}$ & $*$ & $\begin{array}{l}-0.3982 \\
(0.3975)\end{array}$ & \\
\hline Education Category 2 (upper sec.) & $\begin{array}{c}0.3893 \\
(0.1470)\end{array}$ & **** & $\begin{array}{l}-0.0841 \\
(0.1825)\end{array}$ & & $\begin{array}{c}0.0823 \\
(0.3527)\end{array}$ & & $\begin{array}{c}0.0143 \\
(0.3892)\end{array}$ & \\
\hline Education Category 3 (lower sec.) & $\begin{array}{l}-0.0645 \\
(0.1390)\end{array}$ & & $\begin{array}{c}0.0100 \\
(0.1470)\end{array}$ & & $\begin{array}{l}-0.0019 \\
(0.3245)\end{array}$ & & $\begin{array}{l}-0.2104 \\
(0.3642)\end{array}$ & \\
\hline Education Category 4 (vocational) & $\begin{array}{c}0.2713 \\
(0.1229)\end{array}$ & ** & $\begin{array}{c}0.1350 \\
(0.1362)\end{array}$ & & $\begin{array}{l}-0.2508 \\
(0.2915)\end{array}$ & & $\begin{array}{c}0.2018 \\
(0.3432)\end{array}$ & \\
\hline $\log \left(D_{0}\left(0, y_{0}, Z\right)\right)$ & $\begin{array}{c}0.0263 \\
(0.0750)\end{array}$ & & & & & & & \\
\hline Number of Children: 0-2 Years Old & $\begin{array}{c}-0.0436 \\
(0.0427)\end{array}$ & & & & & & & \\
\hline Number of Children: 3-14 Years Old & $\begin{array}{l}-0.0479 \\
(0.0530)\end{array}$ & & & & & & & \\
\hline Number of Children: $15+$ Years Old & $\begin{array}{c}0.0782 \\
(0.0421)\end{array}$ & $*$ & & & & & & \\
\hline Couple & $\begin{array}{c}0.3266 \\
(0.1474)\end{array}$ & ** & & & & & & \\
\hline Widow & $\begin{array}{c}0.2708 \\
(0.4140)\end{array}$ & & & & & & & \\
\hline Divorced & $\begin{array}{c}0.1614 \\
(0.1432)\end{array}$ & & & & & & & \\
\hline$m$ & & & & & $\begin{array}{c}3.3704 \\
(0.1895)\end{array}$ & *** & & \\
\hline$s$ & & & & & $\begin{array}{c}0.1711 \\
(0.0275)\end{array}$ & *** & & \\
\hline $\mathrm{s}_{1}$ & & & & & & & $\begin{array}{c}2.8649 \\
(0.2344)\end{array}$ & \\
\hline $\mathrm{s}_{2}$ & & & & & & & $\begin{array}{l}60.4063 \\
(8.2833)\end{array}$ & 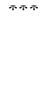 \\
\hline$\rho_{\text {Employment, CES }}$ & $\begin{array}{c}0.9981 \\
(0.1608)\end{array}$ & $\cdots$ & & & & & & \\
\hline$\rho_{\text {Minimum Wage, Working Time }}$ & $\begin{array}{l}-0.2146 \\
(0.1865)\end{array}$ & & & & & & & \\
\hline$\rho_{\text {Employment, Minimum Wage }}$ & $\begin{array}{l}-0.4105 \\
(0.4020)\end{array}$ & & & & & & & \\
\hline$\rho_{\text {Employment, Working Time }}$ & $\begin{array}{l}-0.1806 \\
(0.5134)\end{array}$ & & & & & & & \\
\hline \# observations & 1303 & & & & & & & \\
\hline
\end{tabular}


Table 1 (Continued): Results of Selection-Corrected CES and Wage - Working Time Models

\begin{tabular}{|c|c|c|c|c|c|c|c|c|}
\hline \multicolumn{9}{|c|}{ Women } \\
\hline & Selection & & CES & & Wage & & Working time & \\
\hline Intercept & $\begin{array}{l}-0.7189 \\
(0.1650)\end{array}$ & **** & $\begin{array}{l}-0.6495 \\
(0.4596)\end{array}$ & & $\begin{array}{c}1.0297 \\
(0.4738)\end{array}$ & ** & $\begin{array}{l}-1.2948 \\
(0.5563)\end{array}$ & ** \\
\hline Age & $\begin{array}{l}-0.0865 \\
(0.3555)\end{array}$ & & $\begin{array}{c}0.9233 \\
(0.1793)\end{array}$ & $* * *$ & $\begin{array}{l}-1.6578 \\
(0.9105)\end{array}$ & * & $\begin{array}{l}-1.0051 \\
(1.1546)\end{array}$ & \\
\hline $\mathrm{Age}^{2}$ & $\begin{array}{l}-0.0259 \\
(0.3566)\end{array}$ & & $\begin{array}{l}-1.1507 \\
(0.1679)\end{array}$ & *** & $\begin{array}{c}1.7457 \\
(0.9071)\end{array}$ & $*$ & $\begin{array}{c}0.6519 \\
(1.2394)\end{array}$ & \\
\hline French Nationality & $\begin{array}{l}-0.0708 \\
(0.1404)\end{array}$ & & $\begin{array}{l}-0.0381 \\
(0.2440)\end{array}$ & & $\begin{array}{l}-0.0250 \\
(0.3234)\end{array}$ & & $\begin{array}{l}-0.1902 \\
(0.4287)\end{array}$ & \\
\hline Paris Region & $\begin{array}{l}-0.0073 \\
(0.1252)\end{array}$ & & $\begin{array}{l}-1.0405 \\
(0.2799)\end{array}$ & *** & $\begin{array}{l}-0.1011 \\
(0.2119)\end{array}$ & & $\begin{array}{c}0.4475 \\
(0.2411)\end{array}$ & * \\
\hline Education Category 1 (higher) & $\begin{array}{c}0.8201 \\
(0.1513)\end{array}$ & $* * *$ & $\begin{array}{l}-0.3595 \\
(0.3259)\end{array}$ & & $\begin{array}{l}-0.9690 \\
(0.3141)\end{array}$ & $* * *$ & $\begin{array}{c}0.6905 \\
(0.4731)\end{array}$ & \\
\hline Education Category 2 (upper sec.) & $\begin{array}{c}0.7031 \\
(0.1421)\end{array}$ & *** & $\begin{array}{l}-0.0706 \\
(0.2945)\end{array}$ & & $\begin{array}{l}-0.2176 \\
(0.3363)\end{array}$ & & $\begin{array}{l}-0.1503 \\
(0.5309)\end{array}$ & \\
\hline Education Category 3 (lower sec.) & $\begin{array}{c}0.2055 \\
(0.1252)\end{array}$ & & $\begin{array}{c}0.0654 \\
(0.2337)\end{array}$ & & $\begin{array}{l}-0.1392 \\
(0.2872)\end{array}$ & & $\begin{array}{l}-0.4740 \\
(0.5223)\end{array}$ & \\
\hline Education Category 4 (vocational) & $\begin{array}{c}0.4135 \\
(0.1204)\end{array}$ & $* * *$ & $\begin{array}{c}0.1091 \\
(0.2414)\end{array}$ & & $\begin{array}{c}0.1031 \\
(0.3122)\end{array}$ & & $\begin{array}{l}-0.1118 \\
(0.5063)\end{array}$ & \\
\hline $\log \left(D_{0}\left(0, y_{0}, Z\right)\right)$ & $\begin{array}{c}0.1838 \\
(0.0648)\end{array}$ & $* * *$ & & & & & & \\
\hline Number of Children: 0-2 Years Old & $\begin{array}{l}-0.3549 \\
(0.0576)\end{array}$ & $* * *$ & & & & & & \\
\hline Number of Children: 3-14 Years Old & $\begin{array}{l}-0.1364 \\
(0.0602)\end{array}$ & ** & & & & & & \\
\hline Number of Children: $15+$ Years Old & $\begin{array}{l}-0.0501 \\
(0.0446)\end{array}$ & & & & & & & \\
\hline Couple & $\begin{array}{l}-0.4618 \\
(0.1133)\end{array}$ & $* * *$ & & & & & & \\
\hline Widow & $\begin{array}{l}-0.5580 \\
(0.2338)\end{array}$ & ** & & & & & & \\
\hline Divorced & $\begin{array}{l}-0.0740 \\
(0.0986)\end{array}$ & & & & & & & \\
\hline$m$ & & & & & $\begin{array}{c}3.4005 \\
(0.1935)\end{array}$ & $* * *$ & & \\
\hline$s$ & & & & & $\begin{array}{c}0.1981 \\
(0.0349)\end{array}$ & $* * *$ & & \\
\hline $\mathrm{s}_{1}$ & & & & & & & $\begin{array}{c}2.5135 \\
(0.3361)\end{array}$ & *** \\
\hline $\mathrm{s}_{2}$ & & & & & & & $\begin{array}{l}38.6605 \\
(3.1113)\end{array}$ & *** \\
\hline$\rho_{\text {Employment, CES }}$ & $\begin{array}{c}0.4028 \\
(0.2714)\end{array}$ & & & & & & & \\
\hline$\rho_{\text {Minimum Wage, Working Time }}$ & $\begin{array}{l}-0.3294 \\
(0.1767)\end{array}$ & * & & & & & & \\
\hline$\rho_{\text {Employment, Minimum Wage }}$ & $\begin{array}{l}-0.5487 \\
(0.2921)\end{array}$ & * & & & & & & \\
\hline$\rho_{\text {Employment, Working Time }}$ & $\begin{array}{c}0.5592 \\
(0.3021)\end{array}$ & * & & & & & & \\
\hline \# observations & 1461 & & & & & & & \\
\hline
\end{tabular}


Table 2: Gains to Work by Household Type

\begin{tabular}{|c|c|c|c|c|c|c|c|c|c|}
\hline \multirow[b]{3}{*}{ Household Type } & \multicolumn{9}{|c|}{ Monthly gains per adult equivalent } \\
\hline & \multicolumn{3}{|c|}{ Baseline simulation } & \multicolumn{3}{|c|}{ Without Intéressement, no job loss } & \multicolumn{3}{|c|}{ With Intéressement and job loss } \\
\hline & $\%$ positive gains & Mean & Median & $\%$ positive gains & Mean & Median & $\%$ positive gains & Mean & Median \\
\hline All beneficiaries & 0.99 & 174.62 & 103.70 & 0.86 & 173.48 & 103.70 & 0.98 & 14.53 & 8.53 \\
\hline Single female, no children & 0.97 & 224.20 & 103.70 & 0.85 & 222.33 & 103.70 & 0.97 & 18.84 & 8.53 \\
\hline Single female, 1 child & 0.99 & 99.29 & 69.13 & 0.72 & 97.13 & 69.13 & 0.95 & 9.26 & 5.69 \\
\hline Single female, $>2$ children & 1.00 & 93.90 & 71.19 & 0.88 & 93.28 & 71.19 & 0.99 & 7.83 & 5.91 \\
\hline Single male, no children & 0.99 & 281.30 & 103.70 & 0.95 & 280.74 & 103.70 & 0.99 & 22.62 & 8.53 \\
\hline Single male, with children & 1.00 & 139.38 & 69.13 & 0.94 & 138.80 & 69.13 & 0.99 & 11.47 & 5.69 \\
\hline Couple, no children & 0.99 & 104.88 & 61.00 & 0.86 & 103.91 & 61.00 & 0.97 & 8.99 & 5.02 \\
\hline Couple, 1 child & 0.99 & 83.29 & 47.14 & 0.80 & 82.06 & 47.14 & 0.97 & 7.42 & 3.88 \\
\hline Couple, 2 children & 0.98 & 63.05 & 38.41 & 0.80 & 61.99 & 38.41 & 0.98 & 5.70 & 3.16 \\
\hline Couple, $>2$ children & 0.99 & 65.22 & 32.46 & 0.86 & 64.61 & 32.45 & 0.99 & 5.53 & 3.01 \\
\hline
\end{tabular}

Monthly gains increase as a percentage of non-employment income

\begin{tabular}{lccccccccc} 
& \multicolumn{3}{c}{ Baseline simulation } & \multicolumn{3}{c}{ Without Intéressement, no job loss } & \multicolumn{3}{c}{ With Intéressement and job loss } \\
\cline { 2 - 9 } Household Type & \% positive gains & Mean & Median & \% positive gains & Mean & Median & \% positive gains & Mean & Median \\
\hline All beneficiaries & 0.99 & 0.46 & 0.21 & 0.86 & 0.46 & 0.21 & 0.98 & 0.04 & 0.02 \\
Single female, no children & 0.97 & 0.57 & 0.32 & 0.85 & 0.56 & 0.32 & 0.97 & 0.05 & 0.03 \\
Single female, 1 child & 0.99 & 0.23 & 0.14 & 0.72 & 0.23 & 0.14 & 0.95 & 0.02 & 0.01 \\
Single female, 2 children & 0.97 & 0.21 & 0.12 & 0.78 & 0.21 & 0.12 & 0.97 & 0.02 & 0.01 \\
Single female, > 2 children & 1.00 & 0.25 & 0.19 & 0.88 & 0.25 & 0.19 & 0.99 & 0.02 & 0.02 \\
Single male, no children & 0.99 & 0.75 & 0.32 & 0.95 & 0.74 & 0.32 & 0.99 & 0.06 & 0.03 \\
Single male, with children & 1.00 & 0.31 & 0.14 & 0.94 & 0.31 & 0.14 & 0.99 & 0.03 & 0.01 \\
Couple, no children & 0.99 & 0.28 & 0.15 & 0.86 & 0.28 & 0.15 & 0.97 & 0.02 & 0.01 \\
Couple, 1 child & 0.99 & 0.25 & 0.13 & 0.80 & 0.24 & 0.13 & 0.97 & 0.02 & 0.01 \\
Couple, 2 children & 0.98 & 0.19 & 0.11 & 0.80 & 0.19 & 0.11 & 0.98 & 0.02 & 0.01 \\
Couple, > 2 children & 0.99 & 0.20 & 0.11 & 0.86 & 0.20 & 0.11 & 0.99 & 0.02 & 0.01
\end{tabular}

Source: Authors' calculations based on the Devenir des personnes sorties $d u$ RMI survey. Gains are based on estimated wages and hours potentially offered by employers. They are measured in Euros, and are computed as monthly flow from intertemporal wealth. The equivalence scale uses weights: 1 for first adult, 0.7 for second adult and 0.5 for children. 
Table 3: Gains to Work by Employment status

\begin{tabular}{|c|c|c|c|c|c|c|c|c|c|}
\hline \multirow[b]{3}{*}{ Household Type } & \multicolumn{9}{|c|}{ Monthly gains per adult equivalent (baseline simulation) } \\
\hline & \multicolumn{3}{|c|}{ Observed Gains } & \multicolumn{3}{|c|}{$\begin{array}{c}\text { Simulated gains } \\
\text { on employed population }\end{array}$} & \multicolumn{3}{|c|}{$\begin{array}{c}\text { Simulated gains } \\
\text { on non-employed population }\end{array}$} \\
\hline & $\%$ positive gains & Mean & Median & $\%$ positive gains & Mean & Median & $\%$ positive gains & Mean & Median \\
\hline All beneficiaries & 0.97 & 255.68 & 159.55 & 0.96 & 198.31 & 103.70 & 0.99 & 166.16 & 103.70 \\
\hline Single female, no children & 0.98 & 385.53 & 348.51 & 0.93 & 259.77 & 103.70 & 0.99 & 209.40 & 103.70 \\
\hline Single female, 1 child & 0.90 & 252.03 & 290.88 & 0.99 & 98.13 & 69.13 & 1.00 & 99.79 & 69.13 \\
\hline Single female, 2 children & 0.97 & 181.50 & 200.64 & 0.90 & 86.84 & 51.85 & 1.00 & 83.43 & 51.85 \\
\hline Single female, $>2$ children & 1.00 & 177.45 & 174.53 & 1.00 & 104.01 & 80.39 & 1.00 & 92.32 & 69.91 \\
\hline Single male, no children & 0.97 & 268.94 & 129.14 & 0.97 & 304.46 & 103.70 & 1.00 & 272.47 & 103.70 \\
\hline Single male, with children & 1.00 & 228.91 & 126.19 & 0.98 & 128.78 & 69.13 & 1.00 & 142.41 & 69.13 \\
\hline Couple, no children & 1.00 & 191.39 & 168.66 & 0.98 & 112.62 & 61.00 & 1.00 & 102.27 & 61.00 \\
\hline Couple, 1 child & 0.96 & 202.85 & 146.47 & 0.97 & 89.98 & 47.14 & 1.00 & 80.40 & 47.14 \\
\hline Couple, 2 children & 1.00 & 97.66 & 98.18 & 0.94 & 66.44 & 38.41 & 0.99 & 62.11 & 38.41 \\
\hline Couple, $>2$ children & 0.97 & 108.35 & 98.71 & 0.98 & 73.97 & 39.69 & 0.99 & 63.43 & 32.41 \\
\hline
\end{tabular}

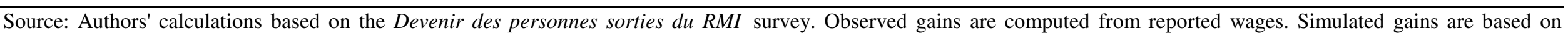

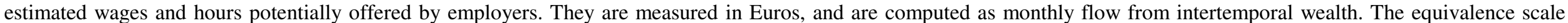
uses weights: 1 for first adult, 0.7 for second adult and 0.5 for children. 
Table 4: Results of the Structural Employment Model

\begin{tabular}{lcccc}
\hline & \multicolumn{4}{c}{ Men } \\
\cline { 2 - 5 } Intercept & -1.1812 & -1.9513 & -1.1315 & -1.156 \\
& $(0.0952)$ & $(0.6981)$ & $(0.0952)$ & $(0.0919)$ \\
Log disposable income & 0.9584 & 0.7945 & 0.3357 & 0.6404 \\
Log hours worked & $(0.1616)$ & $(0.2155)$ & $(0.2409)$ & $(0.2395)$ \\
& & 0.1817 & & \\
Full time dummy (>130 monthly hours) & & $(0.1628)$ & & \\
& & & $(0.1941)$ & $(0.1897)$ \\
Age & -0.3875 & -0.3948 & -0.409 & \\
& $(0.0579)$ & $(0.0585)$ & $(0.0598)$ & \\
\cline { 2 - 5 } Joint significance of disposable income & & & & \\
and hours variable (Wald test) & & 36.98 & 46.33 & 63.99 \\
Number of Observations & & & & \\
Log Likelihood & 820 & 820 & 820 & 820 \\
& -424.6 & -423.95066 & -419.0282 & -444.40802 \\
& & & &
\end{tabular}

Intercept

\begin{tabular}{cccc}
\multicolumn{4}{c}{ Women } \\
\hline-0.9533 & -2.4035 & -0.9252 & -2.1966 \\
$(0.0785)$ & $(0.5061)$ & $(0.0782)$ & $(0.5008)$ \\
0.8883 & 0.4381 & 0.3787 & 0.7319 \\
$(0.2180)$ & $(0.2536)$ & $(0.2906)$ & $(0.2542)$ \\
& 0.3490 & & 0.2889 \\
& $(0.1197)$ & & $(0.1184)$
\end{tabular}

Full time dummy (>130 monthly hours)

0.4705

(0.1986)

Age

$\begin{array}{lll}-0.2818 & -0.2971 & -0.2713\end{array}$

$\begin{array}{lll}(0.0520) & (0.0520) \quad(0.0521)\end{array}$

Number of Children: 0-2 Years Old

$\begin{array}{lll}-0.4393 & -0.4524 & -0.4519\end{array}$

$-0.4144$

$(0.1087)$

$(0.1102)$

$(0.1104)$

$(0.1104)$

Number of Children: 3-14 Years Old

$0.0232 \quad 0.0000$

$-0.0070$

0.0537

$(0.0602) \quad(0.0589)$

$(0.0478)$

$(0.0593)$

Number of Children: 15+ Years Old

$0.0311 \quad 0.0173$

0.0219

$-0.0692$

$(0.0489)$

(0.0492)

(0.0489)

$(0.0477)$

Joint significance of disposable income

and hours variable (Wald test)

$26.65 \quad 22.24 \quad 33.52$

Number of Observations

$\begin{array}{llll}952 & 952 & 952 & 952\end{array}$

Log Likelihood

$\begin{array}{llll}-514.45 & -509.87787 & -511.54768 & -526.44362\end{array}$

Source: Authors' estimates using the Devenir des personnes sorties du RMI survey limited to single persons. Simulated maximum likelihood. See text for specification and normalizations. 
Appendix : Descriptive Statistics

\begin{tabular}{|c|c|c|c|c|}
\hline & \multicolumn{2}{|c|}{ Men } & \multicolumn{2}{|c|}{ Women } \\
\hline & Mean & s.e. & Mean & s.e. \\
\hline$\overline{\text { Age }}$ & 37.5687 & 8.3669 & 36.6742 & 8.4803 \\
\hline French Nationality & 0.8573 & 0.3499 & 0.9199 & 0.2715 \\
\hline Paris Region & 9.5549 & 25.0160 & 7.1355 & 22.0132 \\
\hline Education Category 1 (higher) & 0.1527 & 0.3599 & 0.1123 & 0.3158 \\
\hline Education Category 2 (upper secondary) & 0.1220 & 0.3274 & 0.1211 & 0.3264 \\
\hline Education Category 3 (lower secondary) & 0.1865 & 0.3897 & 0.2416 & 0.4282 \\
\hline Education Category 4 (vocational) & 0.3400 & 0.4739 & 0.3183 & 0.4660 \\
\hline Education Category 5 (primary) & 0.1988 & 0.3992 & 0.2067 & 0.4051 \\
\hline Couple & 0.2939 & 0.4557 & 0.2327 & 0.4227 \\
\hline Widower / Widow & 0.0084 & 0.0915 & 0.0438 & 0.2047 \\
\hline Divorced & 0.1044 & 0.3059 & 0.2539 & 0.4354 \\
\hline Number of Children: 0-2 Years Old & 0.0837 & 0.2957 & 0.1040 & 0.3229 \\
\hline Number of Children: 3-14 Years Old & 0.3354 & 0.8214 & 0.8172 & 1.0463 \\
\hline Number of Children: 15+ Years Old & 0.1051 & 0.3945 & 0.2005 & 0.4940 \\
\hline Employed & 0.3331 & 0.4715 & 0.3073 & 0.4615 \\
\hline CES contract if employed & 0.2880 & 0.4534 & 0.3675 & 0.4827 \\
\hline Hourly wage if employed & 5.6793 & 2.9676 & 5.3923 & 1.4491 \\
\hline Monthly hours if employed & 129.8867 & 46.4072 & 104.3277 & 44.9366 \\
\hline Entitlement to Intéressement available & 0.8918 & 0.3108 & 0.8652 & 0.3417 \\
\hline Full entitlement to Intéressement if available & 0.6867 & 0.4640 & 0.7658 & 0.4237 \\
\hline Exhausted entitilement to Intéressement if available & 0.2126 & 0.4093 & 0.1416 & 0.3488 \\
\hline Partial entitlement to Intéressement if available & 0.1007 & 0.3010 & 0.0926 & 0.2899 \\
\hline \# observations & 1303 & & 1461 & \\
\hline
\end{tabular}

Source: Authors' calculations based on the Devenir des personnes sorties du RMI survey. 